ARTICLE

\title{
Can the Plight of the European Banking Structural Reforms be a Blessing in Disguise?
}

\section{Hossein Nabilou ${ }^{1,2}$}

Published online: 22 February 2021

(c) The Author(s) 2021

\begin{abstract}
One of the problems perceived to be at the heart of the global financial crisis was an amalgamation of various commercial and investment banking activities under one entity, as well as the interconnectedness of the banking entities with other financial institutions, investment funds, and the shadow banking system. This paper focuses on various measures that aim to structurally separate the banking entities and their core functions from riskier financial activities such as (proprietary) trading or investments in alternative investment funds. Although banking structural reforms in the EU, the UK, and the US have taken different forms, their common denominator is the separation of core banking functions from certain trading or securities market activities. Having reviewed the arguments for and against banking structural reforms and their varieties in major jurisdictions, including the EU, UK, US, France, and Germany, the paper argues that a more nuanced approach to introducing such measures at the EU level is warranted. Given the different market structures across the Atlantic and the lack of conclusive evidence of the beneficial impact of banking structural reforms, the paper concludes that the withdrawal of the banking structural reforms proposal by the European Commission has been a prudent move. It seems that in the absence of concrete evidence, experimenting with structural reforms at the Member-State level would be less costly and would provide for opportunities for learning from smaller experiments that could pave the way for a more optimal approach to banking structural reforms at the European level in the future.
\end{abstract}

Keywords Banking structural reforms $\cdot$ Volcker Rule $\cdot$ Subsidiarization $\cdot$ Ringfencing · Universal banking · Interconnectedness

Hossein Nabilou

h.nabilou@uva.nl

1 Visiting Professor, Amsterdam Law School, University of Amsterdam (UvA), Amsterdam, The Netherlands

2 Research Associate, University College, London Centre for Blockchain Technologies (UCL CBT), London, UK 
JEL Classification F3 · G1 $\cdot \mathrm{G} 2 \cdot \mathrm{G} 3 \cdot \mathrm{K} 2 \cdot \mathrm{N} 2$

\section{Introduction}

The financial market turmoil of 2007-2009 triggered a process of financial regulatory reforms, the effects of which are yet to be fully appreciated. The crisis first began with liquidity problems within the banking industry, which was heavily involved in shadow banking activities. ${ }^{1}$ Although, initially, several other financial institutions were blamed for being culprits in the financial crisis, ${ }^{2}$ to date, it is well established that the banking and shadow banking sectors played an unquestionable role. As the process of legislation in itself is a procyclical process, and often follows the 'boom-bubble-bust-regulate cycle', ${ }^{3}$ the financial crisis was followed by a wave of regulatory reforms ushered into prevent or otherwise preemptively address the negative externalities of the next financial crisis. Among such regulatory reforms, banking structural reforms stand out both due to the amount of controversy they created and the variety of forms they took across the world.

Together with providing payment services, deposit-taking and granting loans constitute the core banking functions, which is also known as commercial banking. ${ }^{4}$ Although the sources of funding and the methods through which commercial banks make loans are varied, such a function remains the core activity of commercial banks. ${ }^{5}$ Over time, banking has expanded from simple core banking functions to universal banking. ${ }^{6}$ Universal banks, which are also known as multifunctional banks, ${ }^{7}$ megabanks, ${ }^{8}$ or broad banks, ${ }^{9}$ combine commercial banking with other activities, sometimes generally known as investment banking activities. Investment banking involves a broad range of activities such as capital market activities, including underwriting, corporate financing, advisory services, mergers, acquisitions, loan restructuring, proprietary trading, dealership, brokerage, market-making services, and offering derivative products and asset management services. ${ }^{10}$

\footnotetext{
${ }^{1}$ Gorton and Metrick (2010), pp 261-312; Shleifer (2010), pp 298-303; Gorton (2010). For a definition of shadow banking see Nabilou and Pacces (2018), pp 7-46.

2 Papageorgiou and Salmon (2010), pp 183-201.

${ }^{3}$ Braithwaite (2008).

${ }^{4}$ Cranston (2007).

${ }^{5}$ Iannotta (2010). See also Bryan (1991), pp 61-74.

${ }^{6}$ Richardson et al. (2010), pp 181-212.

${ }^{7}$ Cranston (2007).

8 Avgouleas (2016), pp 279-307.

${ }^{9}$ Barth et al. (2000), pp 191-204.

${ }^{10}$ Cranston (2007).
} 
The core banking functions involve maturity, liquidity and credit transformation. ${ }^{11}$ In addition, banks provide liquidity to the real economy by providing firms with liquid loans (credit). ${ }^{12}$ These functions give rise to maturity and liquidity mismatches, which are often at the heart of banking crises. Basically, what makes banks systemically important - the disruption of which would disrupt the real economyis their role in credit intermediation, which entails both liquidity and maturity transformation. In addition, since accepting deposits is intricately linked to the provision of transaction accounts to customers (checking and savings accounts), the payment system has often been connected to the liquidity and maturity transformation functions. In other words, any disruption in the maturity and liquidity transformation is very likely to cause payment system disruptions that are likely to have broader systemic implications for the wider economy.

In contrast, the non-core banking functions (investment banking activities) are by their nature opaque and often speculative, which make their monitoring and supervision rather challenging. Furthermore, they are not often essential to performing the core banking functions. Undertaking such non-core banking activities by banks elongates the intermediation chains between lenders and borrowers, which in turn results in increased interconnectivity and counterparty risk within the banking industry. ${ }^{13}$ The policy objective from banking structural reforms is to protect the systemically important core banking functions from the risks originating from the more speculative but non-systemic investment banking activities. Therefore, at the core of the debate on banking structural reforms lies the old controversy over separating commercial banking from investment banking. Traditionally, the US has followed a separationist approach to the banking industry, i.e., investment banking was separate from the commercial banking business. However, the situation in the EU was almost completely different. European banks mainly followed the German-style universal banking model ${ }^{14}$ in which one entity could undertake both investment and commercial banking functions.

Given the novelty of the idea of the banking structural reforms in its current shape, the academic literature on this subject is rather scant. This paper attempts to narrow this gap. This paper proceeds as follows. First, it introduces the concept of structural regulation, puts the banking structural reforms into the broader concept of structural regulation and discusses its necessity within the banking context. Second, it explores the arguments in favour and against the banking structural reforms.

\footnotetext{
11 Pozsar et al. (2013), pp 1-16. Maturity and liquidity transformation is often conducted through taking on-demand liquid deposits and transforming them into long-term relatively illiquid loans. As the firms in the real economy normally need to have long-term investment horizons, they often need to hold longerterm liabilities than their assets, and the provision of long-term loans to firms by the banking industry presents immense benefits to society. However, in doing so, banks end up holding short-term liabilities and long-term assets on their balance sheet.

12 By purchasing illiquid assets and accepting illiquid securities as collateral and providing liquid loans, banks play an important role in providing firms with the needed liquidity. However, in the process, again, banks end up holding illiquid assets and liquid liabilities on their balance sheets, again putting them at risk of an illiquidity crisis and potential bank runs.

13 Liikanen (2012); Adrian and Shin (2010), pp 603-618.

14 Calomiris (1995), pp 257-321.
} 
Third, it presents an overview of the banking structural reforms in the US, EU, UK, France, and Germany. Fourth, it discusses the potential costs and unintended consequences of such reforms. Finally, the paper closes with a few concluding remarks.

\section{Why Structural Regulation for Banking?}

The literature on financial regulation includes various measures for addressing the risks of financial institutions. From among these measures, three overarching approaches to reducing the externalities emanating from the financial institutions stand out. The first set of these measures include price-based regulations such as emission taxes in environmental regulation and capital or liquidity requirements in banking regulation. ${ }^{15}$ These regulations are normally introduced in tandem with enhanced and effective supervisory and resolution mechanisms. Such measures can also be combined with the structural limits on the size and scope of the activities of financial institutions. ${ }^{16}$ The second set of such measures include quantity-based regulation, such as emission quotas in environmental regulation. ${ }^{17}$ In the banking industry, concentration limits, the regulations encouraging the allocation of certain ratios of loans to underprivileged segments of society or regulations requiring a gender balance on boards often take this form. Third, structural regulations are often imposed on the size, structure or scope of the activities of financial institutions. ${ }^{18}$ The scope of such regulations includes separating and moving risky and complex businesses to stand-alone subsidiaries and prohibiting banks from engaging in certain business activities.

The assumption behind structural reforms is that the price-based or quantitybased regulations do not sufficiently address issues in some areas of financial regulation such as capital and leverage requirements. In certain other areas such as bail-in requirements, net stable funding ratio (NSFR) and cross-border resolution frameworks, the laws may not be implemented in a consistent manner. ${ }^{19}$ Overall, there are two main arguments for structural measures as opposed to price-based or quantitybased regulations.

First, it is not clear how robust price-based regulations are and whether they would mitigate tail risks. It appears that structural reforms in the form of activity restrictions can be helpful in managing the risks that cannot be measured and be addressed by price-based regulatory tools. ${ }^{20}$ There are already capital requirements, assessment frameworks for counterparty and market risks, leverage ratio, liquidity standards for short-term as well as long-term funding; however, organizational

\footnotetext{
15 Other examples of price-based regulation may include proactive and intense supervision, an effective resolution framework including effective burden sharing, and cross-border arrangements and enhanced transparency and disclosure.

16 Viñals et al. (2013).

17 Weitzman (1974), pp 477-491.

18 Viñals et al. (2013).

19 Independent Commission on Banking (2011); see also Viñals et al. (2013).

20 Viñals et al. (2013).
} 
complexity would hinder these price-based regulations in reducing risks, for example, by opening up venues for regulatory arbitrage. Within complex corporate structures, to limit the activities deemed to carry greater and difficult-to-measure risks, structural reforms can push such activities out of the corporate structure of a firm altogether. $^{21}$

Second, there would be prohibitive enforcement costs if the price-based or quantity-based regulations are not incentive compatible. In contrast to other modalities of regulation, which rely on rational human reasoning, structural regulation (the variations of which are also known as code-based, architecture-based regulation, designbased regulation or techno-regulation) seeks to 'eliminate undesirable behaviour by designing out the possibility for its occurrence'. ${ }^{22}$ This instrument seeks to eliminate the possibility of non-compliance by eliminating the possibility for the application of human discretion and practical reasoning in its entirety. ${ }^{23}$ For example, it is generically submitted that there is a higher risk of regulatory arbitrage and discrepancies in the implementation of price-based prudential standards that render them virtually ineffective. As a concrete example in the banking industry, capital requirements are price-based regulation; however, as is well known, capital arbitrage has made them ineffective. ${ }^{24}$ For example, by booking securitized assets and illiquid securities as trading assets and using internal risk models, banks managed to ascribe lower levels of capital to such exposures. In this context, if regulations are not incentive compatible, their enforcement would entail greater costs because more resources should be allocated to the supervision and enforcement of such rules. In particular, there is a considerable risk in compliance, especially in cross-border supervision and resolution context. Like other regulatory instruments, structural measures can best be used where there is a high cost of enforcement, which is certain, but a lower probability of success for other price-based techniques. In contrast, price-based regulation may be used where the costs of enforcement are lower, but there is a higher probability of success because they are incentive compatible.

There are various other rationales for introducing banking structural reforms. The proponents of such reforms offer various arguments for introducing such measures. The rest of this paper only discusses the arguments in favour of banking structural reforms that posit that they would mitigate systemic risk, prevent cross-subsidization and moral hazard, mitigate conflicts of interest, contribute to resolvability, and improve risk management. After reviewing the banking structural measures across the Atlantic, the paper will also highlight their potential costs.

\footnotetext{
21 Ibid., pp 7-11.

22 Morgan and Yeung (2007).

23 Ibid. Although some proponents of the design-based regulation argue that it has the promise of one hundred percent effectiveness (see e.g.: Lessig 1996, pp 1403-1411), Karen Yeung identifies reasons as to why these mechanisms can fail. She argues, in particular, that '[t]hose which operate by promoting behavioural change, or seek to change the impact of existing behaviour, are more vulnerable to failure than those which do not. And those which override individual behaviour are the most effective of all.' See Yeung (2008), pp 79-107.

24 Jones (2000), pp 35-58; Acharya and Steffen (2015), pp 215-236.
} 


\subsection{Mitigating Systemic Risk and Insulating Banks from Trading Risks}

One of the main objectives of banking structural reforms is to mitigate the systemic risk and to enhance financial stability by closing the contagion channels via insulating banks from trading risks. Contagion, which lies at the heart of the definition of systemic risk, refers to 'the mechanisms through which shocks propagate from one element of the financial system to another and from the financial system to the real economy'. ${ }^{25}$ The main concern about mixing trading activities with core banking activities is that if a banking entity incurs losses in its trading activities, it might cause the failure of the entire bank that would impair the core banking functions. In turn, the damage to the core banking functions would affect the real economy, which lies at the heart of the definition of systemic risk. Closing contagion channels can be achieved through insulating core banking functions - the disruption of which can negatively affect the real sector of the economy by depriving it of credit-from other functions of banking entities such as investment banking and trading activities. Banking structural reforms achieve this goal by mitigating the risks of cross-contamination of investment and commercial banking through the prohibition of mixed funding and separating the capital allocated to the two fundamentally different banking functions. ${ }^{26}$

As the core banking functions are deemed systemically important, they should not be exposed to the risks of the activities that are not systemically important but are more speculative and riskier and could pose risks to the core banking functions. Such a risk to the core banking functions would be realized in several ways. For example, the losses from trading and other activities might put the solvency of the bank at risk. Furthermore, the bank's managers may use non-traditional activities to benefit themselves while putting the solvency of the bank at risk. In this sense, investment banking activities may be used to loot the bank as the losses may be caused by the underpricing of the bank's services to the managers, who happen to own or operate non-traditional services. ${ }^{27}$ In addition, it is alleged that mixing relationship banking (mainly retail or commercial banking) and transaction-based banking (mainly investment banking) brings about a cultural shift towards greater leverage and larger balance sheets, which only deteriorates the Too-Big-To-Fail (TBTF) problem. $^{28}$

Structural measures can also reduce the interconnectedness of banks and shadow banks, ${ }^{29}$ particularly by limiting the exposure of the banking system to the Alternative Investment Fund (AIF) industry. Non-banks' potential role in credit intermediation can make banks, which have substantial relationships with them, fragile in case of any shocks to the system. For example, Structured Investment Vehicles

\footnotetext{
25 Dijkman (2010). For an estimation of the costs of the crisis on the real sector, see Laeven and Valencia (2012).

26 Financial Stability Board (2014b).

27 Shull and White (1998), p 446.

28 Financial Stability Board (2014b).

29 Liquidity Coverage Ratio (LCR) and NSFR that reduce banks' capacity to engage in maturity transformation are two mechanisms introduced by the Third Basel Accord (Basel III).
} 
(SIVs) engaged in maturity transformation also helped traditional banking entities to conceal the risks of off-balance-sheet items, which proved to be detrimental to the banks' safety and soundness. ${ }^{30}$ The structural measures attempt to close the channels of contagion through which the risks of shadow banks might propagate to the banking system. The lack of transparency and insufficient disclosure, agency problems in the securitization process, regulatory arbitrage, and high levels of leverage in the shadow banking sector would also be among the factors that could justify establishing structural regulation between the banking and shadow banking system. ${ }^{31}$ In this sense, some fragmentation, which may result from the banking structural reforms, may be the intended consequence of the reforms as it may result in reducing the interconnectedness between banks and non-bank financial intermediaries. ${ }^{32}$

\subsection{Cross-subsidization and Moral Hazard}

Another reason for separating core banking from non-core banking entities is that non-core banking activities have risks that should not be undertaken by a government-guaranteed institution. In other words, it is not justifiable to allow the financial institutions to invest on their own accounts while funding their activities at belowmarket rates coming from the government's explicit and implicit guarantees. ${ }^{33}$ Instead, non-core banking activities should be performed by separately capitalized subsidiaries within a holding company structure. ${ }^{34}$ However, this argument is built on the assumption that banks are actually subsidized by governments and that the regulator wants to limit the benefits of public guarantees to the systemically important parts of the financial sector (core banking functions). ${ }^{35}$

To say the least, the literature on cross-subsidization is inconclusive. Some studies suggest that there are substantial implicit and explicit subsides within current schemes of government guarantees offered to banks ${ }^{36}$ due to the inherently fragile banking business model and its susceptibility to bank runs, ${ }^{37}$ and that banks may cross-subsidize trading and private funds using such subsidized funds. According to those studies, these subsidies include explicit guarantees such as deposit insurance schemes ${ }^{38}$

\footnotetext{
30 Financial Services Authority (2009).

31 See European Repo Council (2012).

32 Financial Stability Board (2014b).

33 This argument equally applies to other financial institutions having access to government subsides such as government-sponsored enterprises (GSEs) (e.g., Fannie Mae and Freddie Mac in the US) and implicitly guaranteed enterprises such as those perceived to be too big to fail. See Acharya and Richardson (2012), pp 1-38.

34 Bryan (1991), pp 61-74.

35 Viñals et al. (2013).

36 Kelly et al. (2011).

37 Malysheva and Walter (2010), pp 273-290.

38 Although banks often pay risk-based premiums for deposit insurance, charging a risk-adjusted deposit insurance premium has been dauntingly difficult. See Demirgüç-Kunt and Kane (2002), pp 175-195; Demirgüç-Kunt et al. (2015), pp 155-183; Anginer et al. (2014), pp 312-321 Since taxpayers are the ultimate backstop of the deposit insurance schemes, limiting this cross-subsidization is one of the main objectives of the structural reforms.
} 
and privileged access to the Lender of Last Resort (LOLR) facilities. ${ }^{39}$ Although the controversy over the contribution of deposit insurance to financial stability is far from settled, ${ }^{40}$ it is generally accepted that it has prevented bank runs since their establishment in major jurisdictions. However, deposit insurance may have given rise to certain perverse incentives in the banking industry. Further implicit guarantees for banks are mainly in the form of bailouts for TBTF or too-interconnected-to-fail banks, which again would amplify moral hazard. ${ }^{41}$

The above-mentioned subsidies constitute the gross subsidy. However, regulatory costs (such as the costs of the risk-adjusted deposit insurance premia, maintaining reserves at the central bank and other regulatory costs) should be subtracted from those subsidies. Some authors estimate that the amount of subsidies net of regulatory costs to the US banking system is either negative or close to zero. ${ }^{42}$ Others find that the amount of the subsidy to the banks is not substantial. Recent bank reactions to TBTF designations show that there are no longer any subsidies for big banks, there are even perhaps some negative subsidies. ${ }^{43}$ However, such estimates are dependent upon certain assumptions on the level of regulatory capital, the variance of the bank's investments and the level of potential losses to the deposit insurance fund and whether other elements are included in the subsidies and costs. Mainly absent in those studies are the expectation of bailouts for large banking groups. ${ }^{44}$ If such costs would be included in the gross subsidy figure, it would be hard to argue that there are no subsidies for the banking industry in general. ${ }^{45}$

There are two main problems with cross-subsidization in comingling the core and non-core banking activities within a single banking entity. Such problems have both distributional and welfare effects. Distributional effects arise if those subsidies are allowed to flow to the non-core activities, in which case the bank will have an advantage over its competitors in the operation of its non-core activities. Moreover, those subsidies will incentivize banks to overproduce the non-core services which could have welfare effects in the long run. ${ }^{46}$

Subsidizing banks often leads to excessive risk-taking by TBTF or toointerconnected-to-fail banks; ${ }^{47}$ hence the name too-big-to-fail subsidy. The potential flow of the taxpayer-subsidized funds to private funds in the form of implicit guarantees or the provision of emergency liquidity by their parent banks can incentivize them to engage in opportunistic behaviour, i.e., taking excessive risks at the expense of their parent banks. Their parent banks, in turn, would shift some of their losses to the taxpayers rather than incurring them

\footnotetext{
${ }^{39}$ For the concept of the LOLR, see Bagehot (1873); Freixas et al. (2000), pp 63-84; Calomiris et al. (2016), pp 48-65.

40 Demirgüç-Kunt and Kane (2002), pp 175-195; Demirgüç-Kunt et al. (2015), pp 155-183.

41 Calomiris (1999), pp 1499-1519.

42 Shull and White (1998), p 446. One important question is whether the expansion of a bank to new untraditional activities generates new subsidies or costs for the bank (marginal net subsidy). Ibid.

43 Blinder (2013).

44 Shull and White (1998), p 446.

45 Admati and Hellwig (2013).

46 Shull and White (1998), p 446.

47 Saunders (1994), pp 231-254.
} 
themselves. ${ }^{48}$ This has been evidenced in the bailouts of hedge funds by their parent companies (banking entities) in the Global Financial Crisis (GFC). For example, Bear Stearns, Goldman Sachs, and Citigroup bailed out their internal hedge funds just before their collapse. ${ }^{49}$ In the case of the systemically important Bear Stearns, although the collapse of hedge funds did not impose substantial credit risks on Bear Stearns, the firm bailed out the hedge funds due to reputational concerns that the failure of such entities could raise concerns about the safety and soundness of the firm itself. ${ }^{50}$

\subsection{Mitigating Conflicts of Interest in Universal Banking}

Most of the arguments for conflicts of interest raised in favour of banking structural reforms have their roots in the policy debates preceding the introduction of the Glass-Steagall Act in the US. ${ }^{51}$ It is argued that universal banking provides opportunities for conflicts of interest. In the context of commercial vs. investment banking, conflicts of interest primarily lie in the different roles of commercial and investment banks. Commercial banking traditionally involves taking deposits and granting loans, while investment banks and securities dealers' functions include, inter alia, underwriting, selling, trading, and distributing securities. Thus, a bank acting as both a customer's agent and a dealer in the same transaction inevitably faces conflicts of interest. For instance, an investment bank within a universal banking model that underwrites initial public offerings (IPOs) might ill-advisedly suggest to clients and customers (depositors) that they should buy low-quality and less-promising securities. ${ }^{52}$ To mitigate such conflicts of interest, the Glass-Steagall Act prohibited commercial banks from underwriting securities altogether by separating commercial banking from investment banking. ${ }^{53}$

There are several reasons for the conflicts of interest in the debate on universal banking. ${ }^{54}$

\footnotetext{
${ }^{48}$ For a detailed overview of how the failure of Bear Stearns hedge funds affected the firm, see Cohan (2010). See also Hsu and Moroz (2010), pp 39-56.

49 Duffie (2010), pp 51-72.

50 Cohan (2010).

51 Perino (2010).

52 One of the main cases of conflicts of interest in banks exists between its different departments or divisions. The problem was that the research departments of investment banks were financed by the profits of the investment-banking units. Such a situation gave rise to conflicts of interest between banks' analysts and their investment-banking division because, within such a framework, the banks' analysts might tend to (or be pressured to) recommend securities that their investment banking unit underwrites. In the end, discoveries of such conflicts of interest led to a separation of research and investment banking divisions into two different subsidiaries, or to establishing Chinese walls between research and corporate finance divisions within investment banks. See Heffernan (2005).

53 The Glass-Steagall Act also contained exceptions. For example, commercial banks were allowed to underwrite municipal bonds, US government bonds, and engage in private placements.

54 Benston (1990); Saunders (1985b), pp 17-27.
} 
First, commercial banks have a comparative advantage in constructing debt contracts and monitoring the borrowers. ${ }^{55}$ There are economies of scale and comparative cost advantages in information production for commercial banks that make them more efficient in undertaking better debt monitoring. ${ }^{56}$ In other words, banks are information brokers and can improve social welfare by reducing the costs associated with information asymmetry and moral hazard. ${ }^{57}$ In addition, commercial banking provides banks with access to substantial amounts of non-public information about the financial conditions of the borrower. This is especially significant in commercial banks that engage in relationship lending. This informational advantage might give rise to conflicts of interest. ${ }^{58}$ If commercial and investment banking activities comingle, as is the case in universal banks, the proprietary trading desks of those banks will be well positioned to engage in opportunistic behaviour and exploit non-public information at the expense of customers of the bank.

Second, the conflicts of interest that exist between an investment banker's role in promoting securities issues and the commercial banker's obligation to provide disinterested and neutral advice. This concern about conflicts of interest lies within the investment banking business itself. For example, investment banking units of banking entities or groups offer advisory services to corporate customers on financing, mergers and acquisitions, and many other different issues about firms. Such a role in the financial markets gives them privileged access to a substantial amount of nonpublic information. ${ }^{59}$ Indeed, if the Chinese walls between advising units of universal banks and their trading desks are permeable, the information leaked from the advisory and lending units of banks to trading desks could be used by the traders of the bank to profit from such non-public information, potentially at the expense of customers.

Third, commercial banks might be tempted to make loans to support the price of a security, which is underwritten by the bank's securities affiliate. Specifically, the Glass-Steagall Act was intended to address the conflicts of interest embedded in financing companies by financial intermediaries and those offering securities to investors. ${ }^{60}$ Although some scholars cast doubt on this situation as a serious case of conflicts of interest, ${ }^{61}$ the main concern was that commercial banks, being the main lenders to companies and having good knowledge of their financial situation, would sell risky and about-to-default securities to unsophisticated investors. ${ }^{62}$

Fourth, a potential conflict exists in using the securities affiliate or department of a bank to underwrite new securities in order to repay the unprofitable loans or

\footnotetext{
55 Diamond (1984), pp 393-414; Ramakrishnan and Thakor (1984), pp 415-432; Fama (1985), pp 29-39; Fields et al. (2003), pp 517-534.

56 Diamond (1984), pp 393-414.

57 Ramakrishnan and Thakor (1984), pp 415-432.

58 Benston (1990); Saunders (1985b), pp 17-27.

59 Walter (2004), pp 361-376.

${ }^{60}$ Gande (2008) (providing an overview of potential conflicts of interest in the universal banking model and discussing whether they are of concern for regulators).

61 Kroszner and Rajan (1994), pp 810-832.

62 Zingales (2009), pp 391-425.
} 
non-performing loans made by the same commercial bank. ${ }^{63}$ By underwriting securities that the commercial bank itself is knowledgeable about their questionable value, the commercial bank can benefit from such underwriting by requiring the firm to use the proceeds from the issue to pay off the loan. In so doing, the commercial bank serves itself at the expense of outside investors in the newly issued securities. ${ }^{64}$

Fifth, commercial banks may also be tempted to extract monopoly rents from the information accumulated over the life of the lending relationship. Since the existing relationship between customers and the commercial banks (lending relationship) creates information about the borrower to which only the lending institution has access, the commercial bank can exclude other underwriters because of its informational advantage. ${ }^{65}$ Outside firms trying to compete with the commercial bank that does the underwriting and has an ongoing lending relationship with the firm that is going public may face a winner's curse problem. ${ }^{66}$ An additional source of conflicts of interest regarding informational advantage concerns the existence of lock-in effects. Commercial banks may lock in their clients over the long-term and extract profits from their relationship because they would have an information monopoly originating from the private information generated in the loan monitoring process.

Additional conflicts of interest may arise if the commercial department of the universal bank may have the tendency to place the unsold securities of the issue in the trust account of the bank, which is a source of revenue for the bank. Commercial banks might also be tempted to make loans imprudently to issuers of securities underwritten by the bank or its securities affiliates. In other words, direct lending by the bank to its securities affiliate is a source of additional conflicts of interest. Finally, if a banking entity incurs losses in proprietary trading, it might tend to cover those losses at the expense of clients' interests.

Last but not least, proprietary trading and the activities related to hedge funds involve complex financial products and transactions, such as highly illiquid and hard-to-value structured products. ${ }^{67}$ This inherent complexity further increases the information asymmetry between market participants, mainly between originators and investors of the structured products. Increased information asymmetry breeds opportunistic behaviour and amplifies the concerns for aggravated conflicts of interest. ${ }^{68}$ Overall, it seems that in an imperfect information setting, the broader the range of a financial firm's activities, the greater the likelihood of conflicts of interest. ${ }^{69}$

Although there are private-law mechanisms to reduce the conflicts of interest in universal banking, they are generally perceived to be inadequate in addressing such concerns. ${ }^{70}$ For example, in the US, three categories of laws impose a restriction on banking entities with the aim of reducing conflicts of interest in their dealings

\footnotetext{
63 Gande (2008).

64 Saunders (1985a), pp 207-230; Benston (1990).

65 See Sharpe (1990), pp 1069-1087; James (1992), pp 1865-1885; Rajan (1992), pp 1367-1400.

66 Sharpe (1990), pp 1069-1087; James (1992), pp 1865-1885; Rajan (1992), pp 1367-1400.

67 Financial Stability Oversight Council (2011).

68 See Benston (1990).

69 Avgouleas (2016), pp 279-307.

70 See Financial Stability Oversight Council (2011).
} 
with their customers. Such provisions include the fiduciary duty of loyalty under State laws, the investment advisers' and commodity trading advisers' duty of loyalty under federal and state securities and commodities laws, and the duty of loyalty attached to benefit plans under the Employee Retirement Income Security Act (ERISA). And finally, there is a prohibition under the securities laws on obtaining an advantage by using non-public information about a customer or an issuer, such as laws prohibiting insider trading. Similar provisions exist in the EU, both at the Member-State level and the EU level. In addition, banks have voluntarily erected walls between 'customer-serving activities' (departments engaging in dealing with depositors and extending loans) and other departments (such as proprietary trading desks and departments dealing in securities and mergers and acquisitions and investment banking in general) to prevent information flows.

Despite the market forces and private-law mechanisms, it is argued that within 2 years after the passage of the Gramm-Leach-Bliley Act in the US, which repealed the restrictions of the Glass-Steagall Act, major commercial banks that took full advantage of this Act to engage in all other non-core banking activates ended up being involved in serious corporate financial scandals, including Enron and WorldCom. Nearly all of the investment banking units of the Bank Holding Companies (BHCs) were involved in the violations such as corrupt equity research, facilitating late trading, and market timing by hedge funds at the expense of the ordinary shareholders of in-house mutual funds, and playing the role of principal and intermediary in corporate actions. ${ }^{71}$

In spite of such anecdotal evidence, the conflict between anecdotal evidence and empirical findings is rampant in the banking structural reforms literature. Even from its early days, controversies arose about the overall costs and benefits of the GlassSteagall Act, which separated commercial banking from investment banking, and many commentators questioned its underlying rationale. Empirical research found that universal banking does not give rise to serious abuses of conflicts of interest. ${ }^{72}$ Empirical evidence also suggests that universal banks did not engage in opportunistic behaviour that would originate from such conflicts of interest. ${ }^{73}$ Indeed, the absence of an abuse of conflicts of interest may be due to the private-law solutions to conflicts of interest that apply to both systems, i.e. a system with universal banking and a system in which investment banking and commercial banking are separated. For example, it was estimated that securities underwritten by the banking entity's affiliates within the universal banks outperformed comparable securities underwritten by independent non-conflicted investment banks. What confirms these findings is that the superior performance was mostly attributable to the lower-rated and most information-sensitive issues of securities. ${ }^{74}$ This finding clearly runs counter to the idea that combining investment and commercial banking can increase conflicts of interest.

\footnotetext{
${ }^{71}$ Saunders and Walter (2012), pp 39-59.

${ }^{72}$ For an overview of the empirical findings, see Gande (2008).

73 Puri (1996), pp 373-401.

${ }^{74}$ Kroszner and Rajan (1994), pp 810-832.
} 
Based on this finding, Kroszner and Rajan argue that the investor protection argument, which underlies the role of conflicts of interest for separating investment activities from core banking activities, is not justifiable. ${ }^{75}$ They further argue that since the public markets and rating agencies were aware of the potential conflicts of interest, they imposed a 'lemons market' discount on information-sensitive securities underwritten by the affiliates of commercial banks. In response, the affiliates of the banking entities turned away from underwriting information-sensitive securities and started underwriting securities that were less information-sensitive. ${ }^{76}$ Their finding confirms the idea that the market forces can be effective in limiting the propensity of the affiliates of commercial banks to take advantage of uninformed investors and provide adequate monitoring mechanisms to reign in such potential conflicts of interest. Nonetheless, structural reforms attempt to close any remaining loopholes in the banking entities' involvement in proprietary trading and hedge fund and private equity fund investment. ${ }^{77}$

\subsection{Contribution to Resolvability}

It has long been acknowledged that the intensity and high level of intra-group exposures can be an impediment to the orderly resolution of an insolvent bank. Although such exposures play a beneficial role in risk management, they add complexities in the process of resolution by making it difficult to spin off and sell the viable units or restructure the group. As structural measures are aimed at separating the core banking activities from the exposure and contagion of distress in the trading components of the banking group, they may reduce losses and limit the likelihood of public support for credit institutions in the event of their failure. In this way, both components of a multifunctional bank could be more easily wound down and the likelihood of bailouts or public guarantees would be substantially decreased. Hence, these reforms can provide credibility to the resolution mechanism by ex ante restricting the public guarantees to the core banking businesses. Therefore, structural reforms can enhance market discipline by making sure that there is less public support for the failing banks. ${ }^{78}$

There are several venues through which banking structural reforms may contribute to the resolvability of the banking entities. First, by separating trading entities from core banking functions, structural reforms would contribute to the safety and soundness of the bank and would mitigate the likelihood of bank failure in the first place. Second, structural reforms can make the ever-increasing complexity of the universal banking structures simpler and more transparent, and hence contribute to

\footnotetext{
75 Ibid., pp 829-830.

76 Ibid. Though counterintuitive, it seems that market discipline-inspired self-regulation originated from the reputational concerns in repeated commercial activities (versus enforced self-regulation) and was to a great extent effective in regulating the conflicts of interest in commercial banking. See also Morrison and Wilhelm Jr (2007).

77 Financial Stability Oversight Council (2011).

78 Viñals et al. (2013).
} 
the faster resolvability of the banking entities and a reduction of the amount of losses in the event of a failure of a large bank. By separating core banking entities from the trading entities, the resolution authority will have a better overall view of the structure of the bank and may be made capable of resolving the trading entities of the banking entity while allowing and assisting the smooth operation of the core banking activities. Third, the resolvability of a financial institution would be enhanced by some firm-specific structural measures imposed by the banking recovery and resolution directives and regulations. ${ }^{79}$ The mere separation of risky activities of large complex banks would contribute to the resolvability of banking groups. ${ }^{80}$

In addition, if structural measures are required for the efficient resolution of banking groups, a tailor-made firm-specific recovery and resolution plan can better tackle the problems than the outright across-the-board structural measures. ${ }^{81}$ In this perspective, the EU proposal, ${ }^{82}$ which proposed a baseline of structural reforms for banks exceeding a certain size and activity thresholds, and envisaged the possibility of imposing further firm-specific constraints based on the resolvability assessment, which could be imposed through recovery and resolution plans, would have been a suitable regulatory approach. ${ }^{83}$

Firm-specific structural measures for facilitating efficient and least-cost bank recovery and resolution, which constitute bottom-up approaches to banking structural reforms - as opposed to the ex ante across-the-board structural measures-are also supported by the Financial Stability Board's (FSB) Key Attributes of Effective Resolution Regimes for Financial Institutions. ${ }^{84}$ These measures may include changes to the scope of business or size or to the corporate structure of the group. Although firm-specific structural measures, which fit the risk profile of each individual bank, can reduce complexity and contribute to the better supervision of the bank which in turn would reduce the risk of failure and the costs of resolution, discrepancies in the cross-border resolution regimes and the existence of legal and political constraints may still favour across-the-board structural reforms. ${ }^{85}$ However, an equivalence regime, which creates the possibility of the recognition of other

\footnotetext{
79 Binder (2015a); Binder (2015b).

80 This potential role of banking structural reforms has also been highlighted in the Bank Recovery and Resolution Directive (Directive 2014/59/EU of the European Parliament and of the Council of 15 May 2014 establishing a framework for the recovery and resolution of credit institutions and investment firms and amending Council Directive 82/891/EEC, and Directives 2001/24/EC, 2002/47/EC, 2004/25/ EC, 2005/56/EC, 2007/36/EC, 2011/35/EU, 2012/30/EU and 2013/36/EU, and Regulations (EU) No. 1093/2010 and (EU) No. 648/2012, of the European Parliament and of the Council [2014] OJ L 173/190, hereinafter BRRD). See for example, recital 29, Art. 10(7)(c) BRRD. In addition, structural reforms can be undertaken under the BRRD. See for example, Art. 17(5)(g), Art. 27(1)(g) BRRD.

81 Viñals et al. (2013).

82 European Commission, Proposal for a Regulation of the European Parliament and of the Council on structural measures improving the resilience of EU credit institutions, COM(2014) 43 final (hereafter: EU proposal). This proposal is available at: http://eur-lex.europa.eu/legal-content/EN/TXT/ PDF/?uri=CELEX:52014PC0043\&from=EN (last accessed April 30, 2019).

83 Viñals et al. (2010), p 83; Viñals et al. (2013).

84 Financial Stability Board (2014a).

85 Viñals et al. (2013).
} 
jurisdictions' rules on structural reforms, will allow potential cross-border resolution problems to be reduced.

\section{Approaches to Banking Structural Reforms}

Despite their common objectives and relatively few instruments at regulators' disposal, banking structural reforms across the Atlantic have taken rather divergent paths particularly in terms of their scope and strictness. First, in terms of scope, the structural measures often differ on where the separation line is to be drawn. In other words, there is a considerable difference in the scope of the activities that should be separated from the core banking functions. Second, in terms of strictness, there is a significant divergence in how strict, thick or tall the wall standing in between separated activities should be. ${ }^{86}$

In what follows, for the purposes of comparison, the paper investigates the banking structural reforms in the main banking jurisdictions of the US, EU, UK, Germany, and France. However, it should be mentioned that these jurisdictions are not the only ones to introduce structural reforms for their banking industry. Other European Economic Area (EEA) jurisdictions such as Belgium and Switzerland have already established such reforms. Other major banking jurisdictions, which account for a substantial amount of banking assets, especially those jurisdictions that are home to many Global Systemically Important Banks (G-SIBs) have introduced such measures or are considering them. However, some EU jurisdictions hosting G-SIBs (such as Italy, the Netherlands, Spain, and Sweden) have not issued structural reform proposals other than the one proposed by the European Commission. ${ }^{87}$ Outside Europe, steps towards banking structural reforms are being taken in China and Japan. ${ }^{88}$

Overall, there are five main approaches to structural measures for regulating the banking industry:

1. Activity restrictions: These constraints may include the restrictions placed on the prohibition of the proprietary trading by banks, such as what has been undertaken in the US by the Volcker Rule, or the measures proposed by the proponents of narrow banking. ${ }^{89}$ Such activity restrictions are often accompanied by imposing stricter requirements related to capital, intra-group exposure limits, liquidity, and funding sources on parts of a banking organization.

2. Structural separation of certain activities such as ring-fencing of the deposittaking functions and requiring or incentivizing banks to operate through certain

\footnotetext{
${ }^{86}$ In addition, the differences between national proposals within the EU span from institutional, geographic features to the differences in the nature and scope of the separation in the banking sector. On top of them, the US has also introduced new rules for foreign banks which requires them to be structured in the form of an intermediate holding company, which was followed by a similar proposal by the EU.

${ }^{87}$ Financial Stability Board (2014b).

${ }^{88}$ See ibid., pp 11-12.

${ }^{89}$ Simons (1934). For recent discussions, see Bossone (2001); Kay (2009).
} 
structures (e.g., subsidiaries rather than branches), ${ }^{90}$ and restrictions on banking affiliates.

3. Restrictions on the corporate structure of a banking entity, such as the prohibition on branching, which gave rise to the unit-banking phenomenon in the US.

4. Size limits on the banking entities.

5. Geographic restrictions on banking entities.

Many jurisdictions use a combination of these techniques such as the EU proposal which combines structural subsidiarization of the core banking entity and the trading entity and imposing activity restrictions on those entities. In the US banking history, the combination of geographic restrictions and limitations on corporate structures gave rise to banking phenomena such as dual banking, unit banking, branch banking, chain banking, etc., the study of which goes beyond the scope of this paper. The modern forms of banking structural reforms rely on a combination of activity restrictions and structural separation.

A review of the basic legal documents on banking structural reforms shows that structural reforms - in their current forms - can have at least two major sources. First, the laws and regulations that delineate the banking powers (activity restrictions), which could include a functional separation of different types of financial activities by placing outright prohibitions on them. Second, the laws and regulations that set structural restrictions on banking entities, such as ring-fencing and subsidiarization for certain activities that should be conducted in separately capitalized entities within a single holding company structure. In other words, these limitations require that the banking entity can engage in certain business activities provided that the entity complies with certain structural limitations. Other examples of these limitations are those attempting to address conflicts-of-interest concerns by establishing Chinese walls between different departments of a banking entity. The third source of legal intervention originates from the laws that impose geographic restrictions by requiring subsidiarization requirement for the domestic operation of foreign banks, which also forms part of the structural measures. ${ }^{91}$

\subsection{Activity Restrictions: From Narrow Banking to the Glass-Steagall to the Volcker Rule}

In general, within the US context, banks have 'enumerated' as well as 'incidental' powers. Enumerated powers of a bank are those that are explicitly enumerated in the statutes and relevant rules and regulations. In contrast, incidental powers are those that are 'necessary to carry on the business of banking', even if not enumerated in the statutes or other regulations. ${ }^{92}$ In main banking jurisdictions, the core banking activities, i.e., accepting deposits and granting credit by a variety of means, as well

\footnotetext{
90 Financial Stability Board (2014b).

91 Ibid., p 1.

9212 USC $\$ 24$ (Seventh).
} 
as offering payment services are at the core of enumerated banking powers. ${ }^{93}$ In addition, there are activities that are prohibited for banks in statutes.

In the US, the powers of banks regarding real property, securities and insurance have been specifically addressed in statutes. Unless otherwise permitted, banks are prohibited from owning and investing in real property, ${ }^{94}$ owning corporate stocks or underwriting corporate securities, ${ }^{95}$ underwriting insurance, ${ }^{96}$ and charging interest above the legal rate. ${ }^{97}$ Unless there is an incidental power available to a bank, the general rule on banking powers is that if statutes and regulations are silent about certain activities, banks cannot undertake them. ${ }^{98}$ The same rule applies equally to banks in Europe, where Annex I of the Capital Requirements Directive (CRD IV) ${ }^{99}$ enumerates the banking powers and what lies outside would not be allowed for a banking entity. ${ }^{100}$

Perhaps the most intrusive types of structural reforms of the banking industry based on activity restrictions have been narrow banking initiatives. Narrow banking proposals intend to strictly limit the types of assets that the demandable deposittaking institution can hold. A narrow bank is defined as 'a financial institution that issues demandable liabilities and invests in assets that have little or no nominal interest rate and credit risk'. ${ }^{101}$ The most radical of all these proposals was the narrow banking proposal for a $100 \%$ currency-reserve banking, pioneered by Henry Simons in the aftermath of the Great Depression. ${ }^{102}$ This means that all customer deposits should be held at central banks in the form of deposit, which is equivalent to a $100 \%$ reserve requirement. In other words, the amounts that can be redeemed at any time at par value should have a $100 \%$ reserve requirement. This proposal is part of the proposals that came to be known as the Chicago Plan in the aftermath of the Great Depression. ${ }^{103}$ At the heart of the narrow banking solutions to the banking crises is the separation of banks into two parts: a narrow bank offering deposits and a mutual fund or investment company in which all the risks of volatility in the market

\footnotetext{
9312 USC $\$ 24$.

9412 USC $\$ 29$. However, there are certain exceptions to this rule. For example, banks can hold real property if it is pursuant to a foreclosure on a debt, is acquired in 'satisfaction of debts previously contracted in the course of its dealings', is 'necessary for its accommodation in the transaction of its business', or is for the purposes of making investments to promote 'the public welfare, including the welfare of low- and moderate-income communities or families (such as by providing housing, services, or jobs)'. 12 USC $\$ 29$.

9512 USC \$ 24 (Seventh).

9615 USC $\$ 6712(\mathrm{a})$.

9712 USC $\$ 85$.

98 Carnell et al. (2009).

99 Directive 2013/36/EU [2013] OJ L 176/338.

100 As an outgrowth to judicial decisions and as a conceptual framework, it is proposed that in defining the business of banking three key factors should be taken into account: 1 . Whether the activity is a contemporary functional equivalent or outgrowth of recognized banking functions; 2 . Whether the activity benefits customers and/or strengthen the bank; 3 . Whether the risks of the activity are similar to the type of risks already assumed by the bank. See Williams and Jacobsen (1995), pp 783-816.

101 Pennacchi (2012), pp 141-159.

102 Simons (1934); Simons (1936), pp 1-30.

103 For a discussion of the Chicago Plan, see Benes and Kumhof (2012).
} 
value of assets pass through to the investors. ${ }^{104}$ Thus far, narrow banking proposals have not been implemented in any major banking jurisdiction.

\subsubsection{The Volcker Rule}

The US Volcker Rule (title VI of the Dodd-Frank Wall Street Reform and Consumer Protection Act) is a two-pronged provision. It introduces restrictions on proprietary trading, as well as prohibitions on the investments in and sponsorship of hedge funds by banking entities. The proprietary trading provisions of the Volcker Rule prohibit a banking entity ${ }^{105}$ from engaging in trading activities as a principal to profit from the near-term price movements. ${ }^{106} \mathrm{~A}$ 'banking entity' is defined as 'any insured depository institution, ${ }^{107}$ any company that controls an insured depository institution, or that is treated as a bank holding company [...], and any affiliate or subsidiary ${ }^{108}$ of any such entity'. ${ }^{109}$ The term 'proprietary trading' when used with respect to a banking entity or a Systemically Important Non-Bank Financial Company (SIN$\mathrm{BFC}$ ) means "engaging as a principal for the trading account ${ }^{110}$ of [a] banking entity or [a SINBFC] in any transaction to purchase or sell, or otherwise acquire or dispose of, any security, any derivative, any contract of sale of a commodity for future delivery, any option on any such security, derivative, or contract, or any other security or financial instrument that the appropriate Federal banking agencies, the [Securities

\footnotetext{
104 However, narrow banking also has its own critiques. Traditional banks are financed by deposit to make loans, but they follow the fractional reserve model rather than $100 \%$ reserves. Two main and hardly replicable functions of the banking system are the provision of liquidity both to depositors and borrowers, and expertise in screening applicants for loans and the monitoring of borrowers. In other words, they are expert in reducing information asymmetries between ultimate lenders and borrowers. Such proposals would restrict those specific benefits of the banking system to society. In addition, the mutual fund part of the bank will still be subject to the same runs. Some commentators believe that the implementation of narrow banking (full-reserve, limited purpose, or narrow banking proposals) may in practice create more problems than it intends to solve. See, e.g., Avgouleas (2016), pp 279-307.

105 For the definition of a banking entity, see 12 USC $\$ 1851(\mathrm{~h})(1)$.

10612 USC $\$ 1851(a)$ and (h)(4).

107 An insured depository institution is defined in section 3 of the Federal Deposit Insurance Act (12 USC $\S 1813)$.

108 Under sections 2(d) and 2(k) of the Bank Holding Company Act, the terms 'subsidiary' and 'affiliate' are defined to include 'any company that a bank holding company or other company "controls".'

109 The definition of a 'banking entity' in the Volcker Rule includes affiliates and subsidiaries of a banking entity as well. Such a definition would have certain unintended consequences in that it would subject all advised funds of a banking entity, which are normally considered as affiliates of the bank, to the restrictions of the Volcker Rule. However, setting up an advised fund is an explicitly permitted activity for banks. The potential inclusion of hedge and private equity funds in the banking definition can have several unintended consequences. Therefore, there is a need for excluding the permitted hedge and private equity funds from the definition of the 'banking entity'. See Financial Stability Oversight Council (2011).

110 The statute defines a 'trading account' as '[A]ny account used for acquiring or taking positions in the securities and instruments described in [the definition of - proprietary trading-] principally for the purpose of selling in the near term (or otherwise with the intent to resell in order to profit from short-term price movements), and any such other accounts as the appropriate Federal banking agencies, the [SEC], and the [CFTC] may, by rule [...] determine.' See 12 USC $\$ 1851(\mathrm{~h})(6)$.
} 
and Exchange Commission], and the [Commodity Futures Trading Commission] may $[. .$.$] determine.' 111$

Despite the general ban on proprietary trading, the Volcker Rule accommodates certain exceptions as 'permitted activities'. ${ }^{12}$ These permitted activities mainly involve banking activities perceived to be ultimately beneficial to the broader economy and necessary for maintaining the safety and soundness of financial institutions. ${ }^{113}$ These permitted activities under the Volcker Rule include:

1. market-making related activity;

2. risk-mitigating hedging;

3. underwriting;

4. transactions on behalf of customers;

5. transacting in government securities;

6. certain insurance activities;

7. investments in small business investment companies;

8. public welfare investments;

9. certain qualified rehabilitation expenditures under federal or state tax laws;

10. certain offshore activities; and

11. other activities that Agencies determine would promote and protect the safety and soundness of banking entities and the US financial stability. ${ }^{114}$

The Volcker Rule provisions as related to hedge and private equity funds prohibit a banking entity from investing in or having certain relationships with hedge and private equity funds as defined under the exclusions of the Investment Company Act of $1940 .{ }^{115}$ These restrictions prohibit a banking entity from acquiring or retaining any equity, partnership, or other ownership interest in or sponsoring a hedge fund or a private equity fund. ${ }^{116}$ However, the Volcker Rule accommodates certain de minimis exemptions for investment in private funds.

In addition, in the US, banking entities are prohibited from entering into a "covered transaction' as defined in section $23 \mathrm{~A}$ of the Federal Reserve Act. ${ }^{117} \mathrm{~A}$ 'covered transaction' includes making loans, purchasing assets, extending guarantees, etc. ${ }^{118}$ Therefore, the second condition imposed on the permitted activities of banking entities in connecting with investing in hedge funds and private equity funds is that such activities should be subject to the requirements of section $23 \mathrm{~A}$ of the Federal Reserve Act which imposes strict qualitative and quantitative restrictions on 'covered transactions' between a banking entity and an affiliate.

\footnotetext{
11112 USC $\$ 1851(\mathrm{~h})(4)$.

11212 USC $\$ 1851(\mathrm{~d})(1)$.

113 Financial Stability Oversight Council (2011).

114 Ibid.

115 The Investment Company Act of 1940, 15 USC $\S 80 a-1$ et seq.

11612 USC $\$ 1851(\mathrm{a})(1)(\mathrm{B})$.

11712 USC $\$ 1851(\mathrm{f})$.

11812 CFR 223.3(h) (also known as Regulation W).
} 
In addition, section 23B imposes an 'arm's length' requirement on the terms of any transaction between a banking entity that organizes or offers or sponsors hedge or private equity funds or acts as their investment manager or an adviser to those funds. The arm's length requirement means that these transactions should be concluded on market terms and conditions. Therefore, virtually none of the financial transactions between an insured depository institution and an affiliate should be more favourable than market terms. Such restrictions are particularly effective in reducing the likelihood of conflicts of interest and a transfer of the benefits of banks' deposit insurance and safety net from insured depository institutions to hedge funds. ${ }^{119}$ Furthermore, in the US, the Fed's enhanced prudential standards final rule requires foreign banking organizations with $\$ 50$ billion or more in US non-branch or agency assets (foreign banks) 'to place virtually all of its US subsidiaries underneath a top-tier US intermediate holding company (IHC)'. ${ }^{120}$ This rule is also known as the Intermediate Holding Company (IHC) rule. ${ }^{121}$

\subsubsection{The EU Subsidiarization Requirement}

In November 2011, a High-Level Expert Group on reforming the structure of the EU banking sector chaired by Erkki Liikanen was set up by the then EU Commissioner for Internal Market and Services, Michel Barnier. The mission of the Group was to assess whether additional reforms targeting the structure of the banking entities would reduce the likelihood and the impact of bank failures, would ensure the smooth continuation of vital economic functions, and would better protect retail clients. The Group presented its findings on 2 October 2012, in a report that came to be known as 'the Liikanen Report'. ${ }^{122}$ Based on the findings of this report, a proposal on the banking structural measures improving the resilience of the EU credit institutions was published on 29 January 2014, which is also known as 'the Barnier Proposal'. ${ }^{123}$ The EU proposal on banking structural reforms, which is viewed as the equivalent of the US Volcker Rule, laid down rules aimed at imposing structural changes on TBTF banks by setting restrictions on proprietary trading ${ }^{124}$ by banks and requiring the separation of their commercial banking activities from their

\footnotetext{
119 Financial Stability Oversight Council (2011). See also Viñals et al. (2013).

12012 CFR § 252-Enhanced prudential standards (Regulation YY) (adopted 18 February 2014).

121 More recently, the Financial CHOICE Act of 2017 repealed the restrictions of the Volcker Rule; however, as of the time of writing, this Bill has not been passed by the Senate.

122 Liikanen (2012).

123 European Commission, Proposal for a Regulation of the European Parliament and of the Council on structural measures improving the resilience of EU credit institutions, COM(2014) 43 final (in this article referred to as EU proposal, see above n. 82).

124 In the Dodd-Frank Act, the term 'proprietary trading' when used with respect to a banking entity or Systemically Important Non-bank Financial Company (SINBFC) means 'engaging as a principal for the trading account of [a] banking entity or [SINBFC] in any transaction to purchase or sell, or otherwise acquire or dispose of, any security, any derivative, any contract of sale of a commodity for future delivery, any option on any such security, derivative, or contract, or any other security or financial instrument that the appropriate Federal banking agencies, the [SEC], and the [CFTC] may [...] determine.' See 12 USC $\S 1851(h)(4)$.
} 
proprietary trading activities. ${ }^{125}$ Although this proposal was withdrawn by the European Commission in 2018, its unique approach to structural reforms as well as the likelihood of a resurgence of interest in structural reforms, either in a standalone form or as part of the recovery and resolution plans, makes it a worthwhile regulatory proposal to be reviewed in this section.

The draft proposal of the EC consisted of a ban on proprietary trading and a potential separation of certain trading activities from the deposit-taking entity. ${ }^{126}$ This separation would have imposed the requirement that the deposit-taking entity would be completely distinct from other entities in legal, economic, governance and operational terms. Indeed, the EU proposal was mainly concerned with shielding the core banking functions from the risk of contagion. This goal was pursued by requiring the subsidiarization of some activities and restricting the intra-group exposures within multifunctional banks or conglomerates. ${ }^{127}$ The number of banking entities subject to the EU proposal would have been limited. Unlike the US Volcker Rule, which applies to all banking entities, the EU proposal would have been applicable to only the large EU banks considered to be systemically important. ${ }^{128}$

Entities subject to this regulation would have been prohibited from engaging in proprietary trading, from acquiring or retaining units or shares of AIFs, from investing in derivatives, certificates, indices or any other financial instrument whose performance is linked to shares or units of AIFs, and from holding any units or shares in an entity that engages in proprietary trading or acquires units or shares in AIFs with their own capital or borrowed money and for the sole purpose of making a profit for their own account. ${ }^{129}$

Financial instruments issued by Member States' central governments or by entities such as the multilateral development banks including the European Investment Bank and European Investment Fund and International organizations such as the International Monetary Fund (IMF) and the Bank for International Settlements (BIS) were exempt from the ban on proprietary trading and from the structural separation requirement. ${ }^{130}$ The Commission was granted the power of exempting financial instruments issued by third-country governments with regulatory arrangements at least equivalent to those applied in the Union having zero percent risk weights

\footnotetext{
125 This proposal is viewed as a proposal introducing measures to complete the ambitious legal scheme of creating the European Banking Union. The EU regulators pursue several objectives for creating a banking union, among which breaking the vicious circle between banks and sovereign debt, preventing banking instability, and ensuring that restoring stability in financial institutions does not require spending from the taxpayer's money are the most pronounced. The EU Volcker Rule is also said to be a mix of the Volcker Rule-lite plus a form of UK ring-fencing (lite). See Shearman \& Sterling LLP (2014).

126 Art. 2 EU proposal.

127 Viñals et al. (2013).

${ }^{128}$ Credit institutions, their EU parent banks and their subsidiaries and branches including those in third countries, as well as the EU branches and subsidiaries of non-EU banks having total assets amounting to at least $€ 30$ billion and having trading activities amounting to at least $€ 70$ billion or $10 \%$ of its total assets for a period of three consecutive years would have fallen under the proposed rules. Art. 3 EU proposal.

129 Art. 6(1) EU proposal.

130 Art. 8(2) EU proposal.
} 
and financial instruments issued by regional governments of the Member States having zero percent risk weights. ${ }^{131}$ Other sovereign debt instruments may have been included-upon conforming to certain criteria-in the scope of the exemptions.

Trading activities which are to be separated from core banking activities in the proposed regulation were defined negatively in terms of what they are not rather than in terms of what they are. ${ }^{132}$ The following activities were not considered as trading activities:

1. Taking deposits;

2. Lending;

3. Financial leasing;

4. Payment services, including issuing and administering means of payment such as travellers' cheques and bankers' drafts;

5. Money broking, safekeeping, and the administration of securities;

6. Credit reference services;

7. Safe custody services,

8. Issuing electronic money. ${ }^{133}$

The proposal clearly classified market-making activities as trading activity. ${ }^{134}$ However, this was amended in further rounds of the revision of the proposal and market-making activities were excluded from the definition of trading activities.

The trading entity was prohibited from taking deposits eligible under the Deposit Guarantee Schemes (DGS) except where the deposit related to the exchange of collateral which is related to trading activities. The trading entity was also prohibited from providing payment services except where the payment is ancillary and strictly necessary for the exchange of collateral which is related to trading activities. ${ }^{135}$ However, where a competent authority deems that there is a threat to the financial stability of the core credit institution of the Union financial system as a whole, it may decide to prohibit the core credit institution from carrying out such trading activities. ${ }^{136}$ A credit institution, which is banned from carrying out trading activities, may carry out such trading activities to the extent that the purpose of carrying out such activities is limited to only prudently managing its capital, liquidity, and funding, ${ }^{137}$ or to hedging purposes. ${ }^{138}$

In order to deal with perverse interconnections, to address the contagion channels and to restrict cross-subsidization, the proposal also restricts the intra- and extra-group exposures of credit institutions. Limitations on intra-group exposures ${ }^{139}$

\footnotetext{
131 Art. 8(3) EU proposal.

132 Art. 8 EU proposal.

133 Art. 8(1) EU proposal.

134 Art. 9(1) EU proposal.

135 Art. 20 EU proposal.

136 Art. 10(3) EU proposal.

137 Art. 11(1) EU proposal.

138 Art. 12(1) EU proposal.

139 Art. 14 EU proposal.
} 
require that the transactions with the members of the group should be at arm's length. ${ }^{140}$ The arm's length requirement on the transactions between the core credit institution and the trading entity requires that all such transactions be 'as favourable to the core credit institution as are comparable' transactions involving entities not belonging to the same sub-group. ${ }^{141}$ The proposal prohibits the core credit institution from incurring an intra-group exposure exceeding $25 \%$ of the core credit institution's eligible capital to an entity that does not belong to the same sub-group as the core credit institution does. This limit applies on a sub-consolidated basis. ${ }^{142}$ In calculating the intra-group's large exposure limit, all entities belonging to the same subgroup are considered as one client or one group of connected clients. ${ }^{143}$ Regarding extra-group large exposure limits, in addition to the restrictions imposed by the Capital Requirements Regulation (CRR), ${ }^{144}$ the core credit institution should not incur an exposure in excess of $25 \%$ of the core credit institution's eligible capital to a financial entity, and exposures that in total exceed $200 \%$ of the core credit institution's eligible capital to financial entities. This limit will also apply on an individual and sub-consolidated basis. ${ }^{145}$

The EU parent should ensure that a group that contains both a core credit institution and trading entities should be structured in a way that on a sub-consolidated basis two distinct sub-groups are created, only one of which contains core credit institutions. In other words, two separate sub-groups should be created within the banking group, one for core banking activities, and one for trading activities. ${ }^{146}$ The EU parent should ensure that in the event of the insolvency of the trading entity, the core credit institution can continue its activities. ${ }^{147}$

When a competent authority has prohibited a core credit institution from carrying out certain trading activities and if the core credit institution is part of a group, the trading activities can be carried out only by a group entity (i.e., a trading entity) that is 'legally, economically and operationally separate' from the core credit institution. ${ }^{148}$ The trading entity should not hold any capital instruments or voting rights in the depository institution. ${ }^{149}$ In other words, the trading entity cannot be an affiliate of the depository institution. ${ }^{150}$ Although the core credit institution is prohibited from directly holding capital instruments or voting rights in a trading entity, ${ }^{151}$ if

\footnotetext{
140 Art. 13(7) EU proposal.

141 Art. 13(7) EU proposal.

142 Art. 14(2) EU proposal.

143 Art. 14(1) EU proposal.

144 Para. 1 of Art. 395 of Regulation (EU) No. 575/2013 of the European Parliament and of the Council of 26 June 2013 on prudential requirements for credit institutions and investment firms and amending Regulation (EU) No. 648/2012 [2013] OJ L 176/1.

145 Art. 15(1) EU proposal.

146 Art. 13(3) EU proposal. See also Lehmann (2016).

147 Art. 13(4) EU proposal.

148 Art. 13(1) EU proposal.

149 Art. 13(5) EU proposal.

150 This approach is different from the one adopted by the French and German regulators which allows the subsidiarization of the trading entity to the deposit-taking institution.

151 Art. 13(5) EU proposal.
} 
holding such instruments or voting rights is indispensable for the functioning of the group, the core credit institution is allowed to hold such instruments or voting rights provided that it has taken sufficient measures to mitigate the relevant risks appropriately. ${ }^{152}$ There are also some limitations on the issuance of debt by such entities. The core credit institution and the trading entities are required to issue their own debt on an individual or sub-consolidated basis. ${ }^{153}$

The management structures of the two entities should be independent of each other ${ }^{154}$ and the two entities cannot use the same name. Furthermore, their names should be easily distinguishable. ${ }^{155}$ The proposal also contains certain provisions regarding the management of the core credit institution and the trading entity. It requires that a majority of the members of the management body of the core credit institution and of the trading entity should not consist of persons who are members of the management body of the other entity. Aside from the risk management officer of the parent undertaking, no manager of the other entity should perform an executive function in both entities. ${ }^{156}$ In addition, the name or the designation of the trading entity and the core credit institution should be such that the public can easily identify which entity is a trading entity and which entity is the core credit institution. $^{157}$

It seems that within the context of the EU proposal, the universal banking model that has been dominant in Europe for centuries will continue. However, universal banks would no longer be able to undertake a wide variety of financial activities in a single legal entity. Universal banks should form a holding company structure with separately capitalized subsidiaries; one conducting banking activities and the other trading activities. This structure (mixing trading and deposit-taking within a group structure) was proposed to avert the potential unintended consequence in the form of regulatory arbitrage by banking and the migration of activities to unregulated sectors of the financial system. ${ }^{158}$ It is expected that using the same structure for the banking and trading activities would ensure that the activities will remain subject to the oversight and regulatory requirements on a consolidated basis.

\subsection{The UK: Ring-fencing of Core Activities}

The UK's Financial Services (Banking Reform) Act 2013 is the implementation of the recommendations of the Independent Commission on Banking (ICB) chaired by Sir John Vickers. The ICB was set up in 2010 to study and make recommendations on strengthening and improving competition in the UK banking sector. The results

\footnotetext{
152 Art. 13(5) EU proposal.

153 Art. 13(6) EU proposal.

154 Art. 13(8) EU proposal.

155 Art. 13(10) EU proposal.

156 Art. 13(8) EU proposal.

157 Art. 13(10) EU proposal.

158 See Liikanen (2012).
} 
of the study were published in the Vickers Report, ${ }^{159}$ whose findings helped to shape the current structural reforms in the UK known as ring-fencing measures. ${ }^{160}$ Two key banking structural measures in the UK include the ring-fencing of core banking activities and the treatment of branches of non-EEA banks. ${ }^{161}$

The Banking Reform Act requires a UK banking entity's retail deposits, overdrafts, and associated payment services to be separated and placed in a subsidiary (a 'ring-fenced body'). Under this Act, the deposits can only be accepted by ringfenced bodies. ${ }^{162}$ These entities are barred from engaging in 'excluded activities' such as dealing in investments as a principal ${ }^{163}$ and commodities trading. Therefore, ring-fenced bodies cannot assume exposures to relevant financial institutions outside of their corporate group. The objective is to ensure the continuity of the core banking functions.

Drawing lessons from the difficulties faced by the Volcker Rule's distinction between proprietary trading and hedging activities, ${ }^{164}$ the Vickers Commission proposed a very narrow definition of the spectrum of activities permitted to the ringfenced entity. ${ }^{165}$ Therefore, a key difference between the UK and other jurisdictions is that the UK ring-fencing approach does not distinguish between proprietary trading and other types of trading such as market making. Both of these activities are excluded from the entities that conduct the core banking business. Indeed, the ringfencing approach adopted by the UK turns the structural measures' focus from risky activities toward the deposits and core banking activities.

There are also certain limitations on the scope of the ring-fencing in the UK. The ring-fencing requirement only applies to UK incorporated entities with 'core deposits’ if their corporate group holds more than $£ 25$ bn of core deposits in aggregate. The UK subsidiaries of non-UK banks will also fall within the scope of the ringfencing provisions if they cross the above-mentioned threshold. However, neither the non-UK subsidiaries of UK banks nor the foreign banks' UK branches will fall within the scope of ring-fencing.

The UK ring-fencing measures ${ }^{166}$ are broader in scope. But they have a more nuanced approach towards strictness. ${ }^{167}$ The prohibitions are broader in the sense that they exclude a broader set of banking business from the core banking activities. The excluded activities include securities underwriting and secondary market purchases of loans and other financial instruments. A narrow set of retail banking activities fall within the ring-fenced activities such as retail deposit-taking, overdrafts to individuals, and loans to small and medium-sized enterprises (SMEs). Another set of activities of this type can be conducted within the ring-fence (some other forms

\footnotetext{
159 See UK Independent Commission on Banking (2011).

160 See Part 1 'Ring-fencing' of the UK Financial Services (Banking Reform) Act 2013.

161 Financial Stability Board (2014b).

162 Sect. 142A(1) and 142B(1), (2) Financial Markets and Services Act 2000.

163 Sect. 142D(1), (2) Financial Markets and Services Act 2000.

164 See Nabilou (2017), pp 297-341; Krahnen et al. (2017), pp 66-88.

165 Gambacorta and Van Rixtel (2013).

166 For a comprehensive analysis of the concept of ring-fencing, see Schwarcz (2013), pp 69-109.

167 Gambacorta and Van Rixtel (2013).
} 
of retail and corporate banking which include services to hedge risks). Ring-fenced activities can be comingled with other activities in separate subsidiaries within the same group; however, they are subject to intra-group restrictions (on the size and linkages) that are stricter.

A set of restrictions are also introduced to constrain the extent to which the banking entities within the ring-fence can engage in business with other financial sector firms. Indeed, the UK's ring-fencing approach involves both intra-group and interfirm restrictions (the ring fence). The ring-fenced bodies should not have any exposure to each other. In other words, the ring-fenced entities should not be a shareholder of other entities, therefore they may be prohibited from becoming a parent company of other entities. ${ }^{168}$ The arm's length requirement is applied to contracts concluded with other members of the group. ${ }^{169}$

The UK approach also requires that the ring-fenced bodies should be legally, financially and operationally independent of the rest of their corporate group. ${ }^{170}$ The ring-fenced body should be a legally separate entity and at least half of its board members should be composed of directors who are independent of the rest of the group. The ring-fenced body should also meet capital and liquidity requirements, which will be higher than other entities, on a standalone basis. The UK ring-fencing measures do not prohibit ring-fenced bodies from being structured as part of a group engaging in excluded activities, ${ }^{171}$ but they should be independent of the group. The ring-fenced body should be enabled to make a decision independently of other group members and should not be dependent on their resources. ${ }^{172}$ The ring-fenced body should also be capable of carrying out its own activities should one of the other members become insolvent. ${ }^{173}$ Higher capital requirements may apply to ringfenced bodies. Ring-fenced bodies may be asked to issue specific amounts of debt that can be used to boost the loss-absorbing capacity of the ring-fenced entity. ${ }^{174}$ In the event of the insolvency of the ring-fenced entity, the depositors will enjoy preferential treatment. ${ }^{175}$ The Treasury is allowed to exempt the bank from ring-fencing rules if such an exemption would have no significant adverse effect on the financial system's function in providing core banking services (de minimis exception). ${ }^{176}$

In July 2014, secondary legislation was enacted which provides more details on the Banking Reform Act as well as detailing the banks that will fall within the scope

\footnotetext{
168 Lehmann (2016), pp 176-187.

169 Sect. 142H(5)(a) Financial Markets and Services Act 2000.

170 There are also some limits on the scope of the ring-fencing in the UK. The ring-fencing requirement only applies to UK incorporated entities with 'core deposits' if their corporate group holds more than $£ 25$ bn of core deposits in aggregate. The UK subsidiaries of non-UK banks will also fall within the scope of ring-fencing provisions if they exceed the above-mentioned threshold. However, the non-UK subsidiaries of UK banks will not fall within the scope of ring-fencing. Ring-fencing will also not apply to foreign banks' UK branches.

171 Lehmann (2016), pp 176-187.

172 Sect. 142H(4)(b)(i) Financial Services (Banking Reform) Act 2013.

173 Sect. 142H(4)(c) Financial Services (Banking Reform) Act 2013.

174 Sect. 142Y(1) Financial Services (Banking Reform) Act 2013.

175 See Sect. 13 Financial Services (Banking Reform) Act 2013.

176 Sect. 142A(2)(b) and (3) Financial Services (Banking Reform) Act 2013.
} 
of the ring-fencing requirements, the activities to be ring-fenced and the applicable exemptions. ${ }^{177}$ Banks must be compliant with those rules by 2019. ${ }^{178}$

Unlike the Volcker Rule's approach that only prohibits banks from engaging in proprietary trading and investment in private funds, the limitations in the UK on the ring-fenced activities are broader and more intrusive and cover wholesale and investment banking activities. Unlike drawing the fence around the risky activities à la French and German laws, as will be studied in the next section, the UK approach ring-fences the deposits. The UK regimes would eventually force the banking groups to be broken up into retail and wholesale or investment banking entities. ${ }^{179}$

\subsection{France and Germany}

Banking structural reforms were also introduced in France ${ }^{180}$ and Germany ${ }^{181}$ in 2013. Both measures are similar to the EU proposal. ${ }^{182}$ These measures entered into force on 1 July 2015. ${ }^{183}$ The rationale for introducing banking structural reforms in Germany and France is similar to that of the US, UK and EU, i.e., enhancing financial stability through protecting the deposits and retail banking activities against the risks originating from trading activities, addressing conflicts of interest, and encouraging lending to the real economy. ${ }^{184}$ The main aim of both of these regulatory changes is to limit proprietary trading and investment and the sponsorship of hedge funds and other leveraged investment funds by deposit-taking institutions. The French and German approach also has a limited scope compared to the Volcker Rule. Similar to the EU approach, these reforms are only applicable to Systemically Important Financial Institutions (SIFIs). Different thresholds are used in the definition of a SIFI.

Both Germany and France limit proprietary trading and investment in hedge funds and other leveraged investment funds by deposit-taking institutions. However, unlike the US, Germany and France do not completely prohibit these activities. Indeed, in these two jurisdictions, banks are offered two options of either stopping these activities altogether or conducting them through a subsidiary, which is a separate legal entity solely dedicated to risky activities. In other words, a deposit-taking institution exceeding certain thresholds should either cease to engage in certain trading activities (i.e., proprietary trading and certain relations with hedge funds) or transfer them to an entity which is economically, operationally and legally separated

\footnotetext{
177 See Bank of England (2015).

178 Financial Stability Board (2014b).

179 Lehmann (2016), pp 176-187.

180 Loi no. 2013-672 du 26 juillet 2013 de séparation et de régulation des activités bancaires, J.O. $n^{\circ} 173$ du 27 juillet 2013, p. 12530.

181 Gesetz zur Abschirmung von Risiken und zur Planung der Sanierung und Abwicklung von Kreditinstituten und Finanzgruppen v. 7.8.2013, BGB1. 2013 I p. 3090.

182 Viñals et al. (2013).

183 In France: Art. 4-II of the Loi no. 2013-672. In Germany: § 64s(2) Kreditwesengesetz-KWG (German Banking Act).

184 Financial Stability Board (2014b).
} 
from the deposit-taking entity. ${ }^{185}$ Market making is allowed to be carried out within the entity which takes on the core banking functions. However, if market-making activities threaten the solvency of the deposit-taking institution or one of its affiliates, other than the trading entity, the competent authority-as a backstop measure-can demand the separation of market-making activities. Therefore, the German and French models still adhere to the universal banking model.

The difference between the French and German regimes, as opposed to the US regime, is that the proprietary trading and investments in private funds are not prohibited altogether. Instead, the banks are provided with the option of not undertaking these activities or to undertake them through a subsidiary. Despite the similarities of the German and French approach with the EU proposal, there are a few points at which the German and French measures diverge. First, the most salient difference between the French and German approach is in the attempt to delineate the activities allowed for a deposit-taking institution and its relationship with the trading subsidiary. There are differences in the scope of activities that are prohibited for the deposit-taking institutions as well as the relationships between deposit-taking institutions and their subsidiaries. As an example, French measures prohibit the subsidiary from engaging in certain activities altogether, i.e., high-frequency trading and derivatives transactions with agricultural commodities as an underlying asset. ${ }^{186}$ The German measures, however, impose no such restrictions. In addition, the French measures allow deposit-taking institutions to transact with hedge funds and other leveraged investment funds if they are sufficiently secured, whereas such transactions are not allowed in Germany. ${ }^{187}$

Secondly, the rules on the relationship between the different entities of the group diverge to a certain extent, especially regarding the independence of the subsidiary $v i s-\grave{a}-v i s$ the rest of the group. In France, the subsidiary is a separate legal entity which is solely dedicated to undertaking risky activities, and is prohibited from taking deposits or offering payment services. ${ }^{188}$ Separate capital requirements apply to them individually. ${ }^{189}$ Therefore, banking groups will be split into deposit-taking and trading entities. It is only the trading entity that can be the subsidiary and not vice versa. To limit the bailout prospect of a subsidiary due to reputational impact, in France the commercial name of the subsidiary must be distinct from the name of the parent company. ${ }^{190}$ The French measures also require that the directors of the parent and subsidiary should be different, ${ }^{191}$ whereas there are no such requirements

\footnotetext{
185 Ibid., p 10.

186 Art. 511-48-II Code monétaire et financier (French Financial Services Act).

187 Art. 511-47-I 2 para. 7 Code monétaire et financier (French Financial Services Act).

188 Art. 511-48-I Code monétaire et financier (French Financial Services Act); § 25f(6) Kreditwesengesetz-KWG (German Banking Act).

189 Art. 511-48-I Code monétaire et financier (French Financial Services Act); § 25f(2) Kreditwesengesetz-KWG (German Banking Act).

190 Art. 511-48-I para. 7 Code monétaire et financier (French Financial Services Act).

191 Art. 511-48-I para. 8 Code monétaire et financier (French Financial Services Act).
} 
in Germany, where the subsidiary is only subject to the arm's length requirement. ${ }^{192}$ The arm's length requirement in Germany implies that restrictions on large exposures ${ }^{193}$ will apply to such transactions. In contrast, there is no such requirement in France. In other words, in France, although restrictions on large exposures apply to the transactions between banks and their subsidiaries, the arm's length requirement is not applicable. ${ }^{194}$

Given these differences, it does not seem to be correct to label the German and French approach as identical. ${ }^{195}$ Although the EU proposal prohibits the banking entity from engaging in proprietary trading and investment in AIFs, other subsidiaries within the same banking group are allowed to engage in these activities. The difference between the German and French approach with that of the EU approach is that the German and French approach allows market making by depository institutions without requiring any subsidiarization for that activity; ${ }^{196}$ however, as mentioned earlier, the EU proposal has been further amended to include market-making activities.

One of the interesting aspects that the proposal tries to address is the relationship between the existing regulatory reforms (UK, France, and Germany) on banking structures and the EU proposal. The logic of proposing a regulation was that this piece of legislation would normally supersede the previous Member State-level measures. However, the proposal had a grandfathering clause allowing the laws adopted prior to the publication of the EU proposal (29 January 2014) to continue to apply, provided that certain criteria were met. ${ }^{197}$ A close look at those criteria suggests that those conditions would have allowed the UK to adhere to its legislation. However, the French and German approaches may not have fulfilled those criteria. $^{198}$

\subsection{Discussion: A Cross-jurisdictional Comparison}

As mentioned before, banking structural reforms have taken divergent paths especially in terms of their scope and strictness. The differences between the proposals on banking structural reforms originate from the prevailing banking business models and organizations in each jurisdiction and how deeply they were affected by the GFC. ${ }^{199}$ Accordingly, the differences between national proposals within the EU spans from institutional and geographic features to the differences in the nature and scope of the separation in the banking sector. The starting point for the proposals in

\footnotetext{
$192 \S 25 \mathrm{f}(3)$ Kreditwesengesetz-KWG (German Banking Act).

193 See Art. 387 CRR.

194 Lehmann (2016); Viñals et al. (2013).

195 Lehmann (2016).

196 Viñals et al. (2013).

197 Art. 21 EU proposal.

198 Lehmann (2016).

199 Viñals et al. (2013).
} 
the US, UK, EU, France, and Germany is defining and delineating the core business of banking and the nature of the boundary that should be set between those core and non-core functions in the banking business. In terms of their scope, the structural measures often differ on where the separation line is to be drawn. In other words, there is a considerable difference in the scope of the activities that should be separated from the core banking functions. Second, in terms of strictness, there is a considerable divergence in how strict or how thick and tall the wall standing in between separated activities should be.

Generally speaking, the Volcker Rule is narrower in scope, but stricter. ${ }^{200}$ It only places an outright prohibition on proprietary trading, which is a reflection of the view that the nature of core banking business is fundamentally different from the activities that are prohibited in terms of riskiness and complexity. ${ }^{201}$ In contrast, the Volcker Rule allows market making, risk-mitigating hedging, underwriting, and similar activities on behalf of customers to be undertaken by the banking entities. Significant among its exemptions are transactions in specific instruments such as government securities. ${ }^{202}$ In addition, the Volcker Rule prohibits a depository institution from investing and sponsoring entities that could expose banking entities to risks similar to those of proprietary trading. These prohibitions include investment in and sponsoring private funds (e.g., hedge funds and private equity funds).

Compared to the Volcker Rule, the EU proposal is broader in scope, but it is less strict than the Volcker Rule. ${ }^{203}$ In terms of strictness, unlike the EU proposal on banking structural reforms, the Volcker Rule prohibits mixing trading and other core banking activities in different subsidiaries within the same group. ${ }^{204}$ The prohibitions of the EU proposal include both proprietary trading and market-making activities. ${ }^{205}$ However, this allows trading activities to be mingled with core banking activities within the same group subject to subsidiarization. This proposal, however, sets restrictions on the parents and subsidiaries to address problems of contagion. It requires each subsidiary to be independently capitalized and to have adequate liquidity. In addition, transactions between separate entities within the same group shall be conducted at arm's length. Unlike the EU proposal, subsidiarization of the proprietary trading and hedge and private equity fund activities are not allowed under the Volcker Rule. Therefore, US banks are not allowed to engage in prohibited activities even if they are undertaken in a separate subsidiary of the depository institution. ${ }^{206}$

\footnotetext{
200 Gambacorta and Van Rixtel (2013).

201 Viñals et al. (2013).

202 Gambacorta and Van Rixtel (2013).

203 Ibid.

204 Ibid.

205 In its early draft, the proposal clearly classified market-making activities as trading activity. However, this was later amended and market-making activities were excluded from the definition of trading activities.

206 Viñals et al. (2013).
} 
In addition, one major difference between the EU proposal and the US Volcker Rule is in the approach they have taken to proprietary trading activities. By requiring the market making and proprietary trading to be transferred to a separate entity, ${ }^{207}$ the EU proposal avoids the daunting task of delineating and defining the boundaries between the proprietary trading and other forms of permitted activities under the Volcker Rule which is one of the main challenges in its implementation phase. $^{208}$

In contrast to the UK approach which draws a ring fence around the core banking activities of the banking entity, the EU proposal seems to draw a ring fence around the trading entity in a way to ensure that the insolvency of the trading entity will not affect the core credit institution. ${ }^{209}$ Compared to the UK ring-fencing approach, the scope of the European proposal is narrower. The focus of the UK ring-fencing is on the deposit-taking activities and it is to ring-fence such activities by forcing them to be conducted within a separately capitalized subsidiary. However, the EU proposal focuses on proprietary trading, carves out the proprietary trading and all assets, liabilities and derivatives positions involved in the process of market making and separates them from other banking activities and requires subsidiarization of the proprietary trading activities which should be undertaken separately from the deposit-taking institution on a standalone basis. The separate trading entity can have exposures to hedge funds, special investment vehicles, and private equity investment but not to the deposit-taking institution. However, the trading entity is not allowed to provide retail financial services and is prohibited from funding itself with deposits.

The UK ring-fencing regulation only applies to domestic retail banking and the EU proposal will apply only to the largest EU banks. Within the EU proposal framework, activities such as lending to individuals and businesses, mortgage lending, wealth management, and deposit-taking would be conducted within the same group. Therefore, this approach to structural reforms is less restrictive than the UK ringfencing approach in terms of the scope of the activities that a domestic depository institution is allowed to undertake. ${ }^{210}$

\section{Economic Costs and Potential Unintended Consequences}

It is suggested that the financial crisis has proven that the welfare gains from mixing commercial and investment banking have not been materialized due to three main reasons: the severe agency problems within TBTF banks, homogenization originating from rational herding and capital requirements, and cultural shifts. ${ }^{211}$ If true, it seems that structural reforms can play a role in improving all these three aspects.

\footnotetext{
207 This was later revised to allow for market making to take place in the core credit institution without subsidiarization.

208 Nabilou (2017), pp 297-341; Krahnen et al. (2017), pp 66-88.

209 Art. 13(4) EU proposal.

210 Gambacorta and Van Rixtel (2013).

211 Avgouleas (2016), pp 279-307. For the homogenization problem, see Avgouleas (2012), chapters 2, 3.
} 
However, on the downside, structural reforms are expected to negatively affect financial markets by either reducing liquidity ${ }^{212}$ or increasing the cost of doing banking, which could mean decreasing banking profitability. Other potential alleged negative impacts of the banking structural reforms include a negative impact on the efficiency of cross-border groups, additional complications for the crisis management and the resolvability of cross-border groups, a negative impact on the liquidity of the crossborder groups and an increased likelihood of regulatory arbitrage and shifting some banking activities to the shadow banking system. ${ }^{213}$ Overall, most of the above-mentioned costs can be put into two main categories: the costs arising from the impact of structural reforms on economies of scope and diversification and the costs arising from the impact on the banking business models and profitability.

\subsection{Impact on Economies of Scope and Diversification}

Combining commercial banking, securities and insurance activities within one entity presents several advantages. ${ }^{214}$ These advantages include taking advantage of economies of scale and scope in collecting and processing information, risk diversification, and a more stable source of income stemming from a diversified range of activities. Therefore, such a combination of activities would contribute to banking stability and building long-term reputational capital with clients that can enhance the franchise value of banks and create incentives for them to behave more prudently. ${ }^{215}$

The most outstanding benefits of combining lending with underwriting and other non-core banking activities are the informational advantages and economies of scope. Universal banking can benefit from economies of scope through either informational or cross-selling venues.

\subsubsection{Informational Venues}

A bank acquires information dealing with its customers in the course of its core banking activities, which can be used in its investment banking or trading activities. This can give rise to significant synergies and informational efficiencies. However, as mentioned earlier, this situation can be fraught with conflicts of interest. If conflicts of interest are dealt with effectively, a huge source of informational efficiencies

\footnotetext{
212 Thakor (2012).

213 Financial Stability Board (2014b). For example, as the ring-fencing provisions limit the involvement of the ring-fenced bodies in the lucrative business of investment banking, it is likely that in the end the cost to clients of the ring-fenced banks will rise. See Lehmann (2016), pp 176-187. In addition, the Liikanen Report emphasized that in contrast to complete separation, the mixing of certain activities within the same group will have advantages in terms of limiting regulatory arbitrage (shifting investment banking activities to the lightly regulated shadow banking sector). See Liikanen (2012). See also Gambacorta and Van Rixtel (2013).

214 Barth et al. (2000), pp 191-204. See also Claessens and Klingebiel (2001), pp 19-40.

215 Keeley (1990), pp 1183-1200 (showing that there is a perceived relationship between franchise value and bank managers' incentives to behave prudently). See also Demsetz et al. (1996).
} 
might lie in the synergies arising from combining investment banking and commercial banking within a single entity.

The existence of economies of scope suggests that if there is a fixed cost in lending and underwriting securities in the same firm, the combination of these two functions lowers the information production costs because it prevents duplication of information production (fixed costs). ${ }^{216}$ For example, building a banking relationship entails costs in terms of evaluating a firm's creditworthiness by the commercial bank. Subsequent to such an evaluation, if the same commercial bank wants to underwrite security issues for the same firm, it does not need to incur additional costs in investigating the worth of the firm. Whereas if the same underwriting is undertaken by a separate investment firm, it should incur costs to evaluate the firm. The process can also work in the opposite direction, i.e., the information generated in the process of underwriting can be used in the extension of credit to the same firm. ${ }^{217}$

\subsubsection{Economics of Scope and Cross-selling}

The revenue economies of scope accrue when the overall cost (including search, monitoring, and contracting costs) of purchasing multiple financial services to the buyer from a single seller is lower than the cost of purchasing them from different sellers. The sources of economies of scope can be sharing common facilities, personnel, knowledge and a brand name. ${ }^{218}$ For example, diversified financial intermediaries have more contact points with clients which facilitate cross-selling, e.g., in addition to current accounts, universal banks can offer customers investment accounts, trading accounts, pension schemes, and insurance services. This can increase efficiency in terms of the necessary efforts by the retail customers to be made on shopping for these products in different places. However, there would be a cost to economies of scope. Revenue diseconomies of scope would originate from the management complexities, and conflicts of interest as the scope of activities broaden. ${ }^{219}$ The evidence on economies of scale suggests that an increase in the scale of $100 \%$ (doubling the size) would not reduce the average cost by more than $5 \%$, and estimates of average cost savings in banking through economies of scope is inconclusive. $^{220}$

The empirical evidence suggests that during 1988-1992 in countries where a functional separation was required, large banks had an average operational inefficiency score of $27.5 \%$; however, this number stood at $15 \%$ in countries where universal banking was allowed. ${ }^{221}$ Other studies, ${ }^{222}$ distinguishing between specialized

\footnotetext{
$\overline{216}$ Kanatas and Qi (1998), pp 119-133.

217 Ibid.

${ }^{218}$ Shull and White (1998), p 446.

${ }^{219}$ Saunders and Walter (2012), pp 39-59. See also Duffie (2010), pp 51-72.

${ }^{220}$ Goddard et al. (2007), pp 1911-1935.

${ }^{221}$ Ibid. See also Allen and Rai (1996), pp 655-672.

222 Vennet (2002), pp 254-282.
} 
banks, universal banks and financial conglomerates, found that during 1995-1996 the average operational efficiency of specialized banks was virtually equivalent to that of the conglomerates in traditional intermediation activities. However, in nontraditional activities, conglomerates operate more efficiently. On average, it seems that the operational efficiency in universal banks is higher than in specialized banks. $^{223}$

\subsection{Impact on Banking Business Models and Banking Stability}

The specific features of banking entities, such as the scope of their activities and sources of funding, can be the determinants of their resilience in the face of financial distress. The question is which business models render banks more resilient in distressed situations and which models make them prone to risks. Higher levels of diversification that could be derived from multiple products, client segments, and geographic sectors may be associated with more stable and valuable financial institutions. As the correlation among different sources of a bank's cash flow decreases, the benefits of diversification increase. This would further lead to better credit quality for banks. In turn, better financial standing leads to lower regulatory capital requirements and potential higher profitability. Diversity in the financial sector implies the coexistence of different institutional forms, business models, and earning models and that they would be sufficiently strong so that it would give rise to effective competition among those models. Therefore, diversification may also lead to better earning stability if the diverse activities generate income streams that are not perfectly correlated with the existing income stream of the bank. This combination will reduce unsystematic risks and will lead to a less volatile income stream. ${ }^{224}$ On the contrary, it is more likely that similar institutions may face difficulties at the same time that could lead to the problem of 'too many to fail', ${ }^{25}$ which makes some financial institutions systemic as a group. These arguments would rally against breaking up the multifunctional banking entities. ${ }^{226}$

Historical evidence also bears witness to the positive impact of diversification on banking stability. For example, between 1921 and 1930, the rate of failure among small banks in agricultural regions in the US was approximately $50 \%{ }^{227}$ In addition, the rate of profitability of small banks was smaller than that of larger banks between 1926 and $1930 .{ }^{228}$ According to more recent findings, commercial banks involved in securities underwriting are not riskier than the commercial banks that are not involved in such activities. Not only are such commercial banks not riskier,

\footnotetext{
223 Goddard et al. (2007), pp 1911-1935.

224 Shull and White (1998), p 446.

225 Acharya and Yorulmazer (2007), pp 1-31.

226 Saunders and Walter (2012), pp 39-59.

227 Walter (2005), pp 39-54.

228 Ibid.
} 
but they are also less likely to fail than commercial banks which are not involved in such operations. ${ }^{229}$

However, over the last decades, the similarity between financial institutions has increased. This trend has been more prevalent among large financial institutions. ${ }^{230}$ This similarity manifested itself in the same market (globally), similar activities, similar risk management techniques and similar trading strategies which can amplify the effects of systemic risks. The sources of funding in the banking sector have also converged and effectively the banking sector has increasingly relied on the same sources of funding. Another source of homogeneity in the banking industry comes from interlinkages among institutions. The lack of diversity may present risks in the banking sector. Banking structural reforms may indeed decrease diversification in the business model in banking and could lead to banking instability. However, more recent evidence suggests that the benefits of diversification in terms of returns on equity accrue, to a certain degree, from product diversification at the expense of the higher volatility of bank profitability for more diversified banks. ${ }^{231}$ Therefore, evidence of the economies of scope and diversification on banking stability remains inconclusive at best.

In addition, it is demonstrated that weakly capitalized, larger banks with greater reliance on short-term funding have often had higher risk exposures. On the contrary, banks reliant on a strong deposit base and greater diversified income are considered less risky. ${ }^{232}$ Reliance on short-term wholesale funding resulted in increased financial fragility, ${ }^{233}$ whereas the banks with more stable funding continued to lend more during the financial crisis. ${ }^{234}$ It is shown that universal banks have a greater reliance on short-term wholesale funding, have a higher average size, have greater volatility of earnings, and higher levels of market risk compared to other banking models. ${ }^{235}$ On the other hand, the size and scope could not produce the claimed benefits and especially the benefits of diversification were far more limited than expected and this was by far offset by additional complexity. ${ }^{236}$

Moreover, trading risks are viewed as an indicator of the risk of financial distress. An IMF study suggests that the US and EU banks with substantially greater trading activities than average (measured by the ratio of trading income to revenues) were more likely to need explicit government support than other banks. ${ }^{237}$ This report suggests that proprietary trading might only be a part of the problem, and risks could originate from losses in other activities such as market making, investment banking and hedging strategies. ${ }^{238}$ On the contrary, it is also demonstrated that retail banking

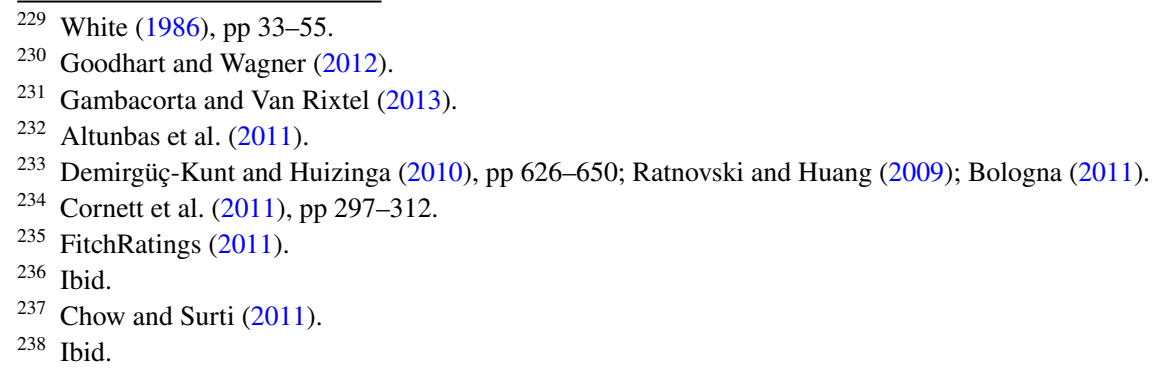


service providers are better in terms of cost efficiency and performance measures. In general, the retail-oriented models of banking seem to be safer than others, both in terms of a lower likelihood of default and better long-term liquidity measures (net stable funding ratio). ${ }^{239}$ In addition, expansionary strategies of the banking institutions to a multifunctional banking model have been found to increase the systematic risk. $^{240}$

The only conclusion that may be derived from the above observations is that although it is believed that in the absence of 'any strong evidence in favour of conglomeration, structural reform is a good way to respond to interconnectedness in financial markets, ${ }^{241}$ as the evidence is not clear that imposing structural reforms can contribute to financial stability, so adequate care must be taken in introducing such measures, in particular at the EU level.

\section{Conclusion}

This paper investigated the arguments for and against the banking structural reforms and studied the structural reforms initiatives in the US, EU, UK, France, and Germany. The paper finds that at the heart of all banking structural reforms lie the variations of the age-old separation between commercial and investment banking. Therefore, most of the arguments against the universal banking model could be used-to varying degrees-for establishing banking structural reforms and limiting the universal banking model.

The paper further investigated the most frequently cited rationales for banking structural reforms such as mitigating systemic risk, preventing cross-subsidization and moral hazard, and mitigating the conflicts of interests in the universal banking model. A closer look at these rationales revealed that there is no conclusive empirical evidence that can support such intuitive insights. Regarding the mitigation of systemic risks, as the structural measures would limit diversification in banking business models and contribute to increasing homogeneity within the banking industry, it is unlikely that they would enhance financial stability. Although it may be argued that structural measures can complement prudential tools, it seems that no specific banking business model is more susceptible to a greater risk of failure, ${ }^{242}$ hence a contribution to financial stability remains very hypothetical. In addition, there is no clear-cut evidence on the amount of net regulatory subsidies for the banking industry to support the argument that the structural reforms would decrease the cross-subsidization of the riskier trading activities by taking advantage of regulatory safety nets. As for the conflicts of interest, although it seems that the amalgamation of banking and trading activities gives rise to conflicts of interest in theory, the banking history and empirical findings suggest that the private-law mechanisms, as

\footnotetext{
239 Ayadi et al. (2012).

240 Richardson et al. (2010), pp 181-212.

241 Avgouleas (2016), pp 279-307.

242 Viñals et al. (2013).
} 
well as market discipline, have already been successful in reducing the risks arising from conflicts of interest. Above all, it seems that the introduction of structural reforms could have been more disruptive to the European banking industry which has always operated within a bank-based financial system relying on the universal banking model.

In the absence of credible and conclusive evidence in favour of structural reforms, the withdrawal of the EU banking structural reforms proposal in 2018 seems to be a step in the right direction as it was in line with the do-no-harm principle and has arguably decreased the impact of a single large-scale regulatory error. Furthermore, this withdrawal would make room for more experimentations with structural reforms at the Member-State level that would allow for alternative solutions to be tested for similar problems. Such experimentations are likely to produce more bottom-up legal and regulatory innovations, differentiated and customized approaches adapted to local circumstances and the idiosyncratic needs of the banking industry as showcased by the differential UK, German and French approaches to structural reforms.

Open Access This article is licensed under a Creative Commons Attribution 4.0 International License, which permits use, sharing, adaptation, distribution and reproduction in any medium or format, as long as you give appropriate credit to the original author(s) and the source, provide a link to the Creative Commons licence, and indicate if changes were made. The images or other third party material in this article are included in the article's Creative Commons licence, unless indicated otherwise in a credit line to the material. If material is not included in the article's Creative Commons licence and your intended use is not permitted by statutory regulation or exceeds the permitted use, you will need to obtain permission directly from the copyright holder. To view a copy of this licence, visit http://creativecommons.org/licen ses/by/4.0/.

\section{References}

Acharya VV, Richardson M (2012) Implications of the Dodd-Frank Act. Annu Rev Financ Econ 4(1): $1-38$

Acharya VV, Steffen S (2015) The 'greatest' carry trade ever? Understanding eurozone bank risks. J Financ Econ 115(2):215-236

Acharya VV, Yorulmazer T (2007) Too many to fail-an analysis of time-inconsistency in bank closure policies. J Financ Intermed 16(1):1-31

Admati AR, Hellwig M (2013) The bankers' new clothes: what's wrong with banking and what to do about it. Princeton University Press, Princeton

Adrian T, Shin HS (2010) The changing nature of financial intermediation and the financial crisis of 2007-2009. Annu Rev Econ 2:603-618

Allen L, Rai A (1996) Operational efficiency in banking: an international comparison. J Bank Finance 20(4):655-672

Altunbas Y, Manganelli S, Marques-Ibanez D (2011) Bank risk during the financial crisis: do business models matter? European Central Bank Working Paper Series No 1394. https://www.ecb.europ a.eu/pub/pdf/scpwps/ecbwp1394.pdf. Accessed 20 Oct 2020

Anginer D, Demirguc-Kunt A, Zhu M (2014) How does deposit insurance affect bank risk? Evidence from the recent crisis. J Bank Finance 48:312-321

Avgouleas E (2012) Governance of global financial markets: the law, the economics, the politics. Cambridge University Press, New York 
Avgouleas E (2016) Large systemic banks and fractional reserve banking: intractable dilemmas in search of effective solutions. In: Buckley RP, Avgouleas E, Arner DW (eds) Reconceptualising global finance and its regulation. Cambridge University Press, New York, pp 279-307

Ayadi R, Arbak E, De Groen WP (2012) Regulation of European banks and business models: towards a new paradigm?. Center for European Policy Studies, Brussels

Bagehot W (1873) Lombard Street: a description of the money market. H.S. King, London

Bank of England (2015) The implementation of ring-fencing: consultation on legal structure, governance and the continuity of services and facilities: policy statement 10/15. https://www.bankofengland. co.uk/prudential-regulation/publication/2014/the-implementation-of-ring-fencing-consultation-onlegal-structure-governance. Accessed 15 Jan 2021

Barth JR, Brumbaugh RD, Wilcox JA (2000) The repeal of Glass-Steagall and the advent of broad banking. J Econ Perspect 14(2): 191-204

Benes J, Kumhof M (2012) The Chicago Plan revisited. International Monetary Fund, Washington, DC

Benston GJ (1990) The separation of commercial and investment banking: the Glass-Steagall Act revisited and reconsidered. The Macmillan Press Ltd, London

Binder J-H (2015a) Resolution planning and structural bank reform within the Banking Union. In: Castañeda JE, Mayes DG, Wood G (eds) European Banking Union. Routledge, Abingdon, pp $147-173$

Binder J-H (2015b) Ring-fencing: an integrated approach with many unknowns. Eur Bus Org Law Rev 16(1):97-119

Blinder AS (2013) After the music stopped: the financial crisis, the response, and the work ahead. Penguin, New York

Bologna P (2011) Is there a role for funding in explaining recent US banks' failures? IMF Working Paper WP/11/180. https://www.imf.org/en/Publications/WP/Issues/2016/12/31/Is-there-a-Rolefor-Funding-in-Explaining-Recent-U-S-25102. Accessed 20 Oct 2020

Bossone B (2001) Should banks be narrowed? IMF Working Paper WP/01/159. https://www.imf.org/ external/pubs/ft/wp/2001/wp01159.pdf. Accessed 20 Oct 2020

Braithwaite J (2008) Regulatory capitalism: how it works, ideas for making it work better. Edward Elgar Publishing Inc, Northampton

Bryan LL (1991) Core banking. McKinsey Quarterly 1:61-74. http://search.ebscohost.com/login . asp ?direct $=$ true $\& \mathrm{db}=$ buh $\& A N=9707250123 \&$ site $=$ ehost-live $\&$ scope $=$ site. Accessed 20 Oct 2020

Calomiris C (1995) The costs of rejecting universal banking: American finance in the German mirror, 1870-1914. In: Lamoreaux NR, Raff DMG (eds) Coordination and information: historical perspectives on the organization of enterprise. University of Chicago Press, Chicago, pp 257-321

Calomiris CW (1999) Building an incentive-compatible safety net. J Bank Finance 23(10):1499-1519

Calomiris CW, Flandreau M, Laeven L (2016) Political foundations of the lender of last resort: a global historical narrative. J Financ Intermed 28:48-65

Carnell RS, Macey JR, Miller GP (2009) The law of banking and financial institutions. Aspen Publishers, New York

Chow JT, Surti J (2011) Making banks safer: can Volcker and Vickers do it? IMF Working Paper WP/11/236. https://www.imf.org/en/Publications/WP/Issues/2016/12/31/Making-Banks-Safer -Can-Volcker-and-Vickers-Do-it-25289. Accessed 20 Oct 2020

Claessens S, Klingebiel D (2001) Competition and scope of activities in financial services. World Bank Res Observ 16(1):19-40

Cohan WD (2010) House of cards: a tale of hubris and wretched excess on Wall Street. Anchor Books, New York

Cornett MM, McNutt JJ, Strahan PE, Tehranian H (2011) Liquidity risk management and credit supply in the financial crisis. J Financ Econ 101(2):297-312

Cranston R (2007) Principles of banking law. Oxford University Press, New York

Demirgüç-Kunt A, Huizinga H (2010) Bank activity and funding strategies: the impact on risk and returns. J Financ Econ 98(3):626-650

Demirgüç-Kunt A, Kane EJ (2002) Deposit insurance around the globe: where does it work? J Econ Perspect 16(2):175-195

Demirgüç-Kunt A, Kane E, Laeven L (2015) Deposit insurance around the world: a comprehensive analysis and database. J Financ Stabil 20:155-183 
Demsetz RS, Saidenberg MR, Strahan PE (1996) Banks with something to lose: the disciplinary role of franchise value. Econ Policy Rev 2(2). http://papers.ssrn.com/sol3/papers.cfm?abstract_ $\mathrm{id}=1028769$. Accessed 20 Oct 2020

Diamond DW (1984) Financial intermediation and delegated monitoring. Rev Econ Stud 51(3):393-414

Dijkman M (2010) A framework for assessing systemic risk. The World Bank Open Knowledge Repository. https://openknowledge.worldbank.org/handle/10986/3768. Accessed 20 Oct 2020

Duffie D (2010) The failure mechanics of dealer banks. J Econ Perspect 24(1):51-72

European Repo Council (2012) Shadow banking and repo. http://www.icmagroup.org/assets/docum ents/Maket-Practice/Regulatory-Policy/Repo-Markets/Shadow-banking-and-repo-20-March -2012.pdf. Accessed 22 Jan 2021

Fama EF (1985) What's different about banks? J Monetary Econ 15(1):29-39

Fields P, Fraser D, Bhargava R (2003) A comparison of underwriting costs of initial public offerings by investment and commercial banks. J Financ Res 26(4):517-534

Financial Services Authority (2009) The Turner Review: a regulatory response to the global banking crisis. http://www.actuaries.org/CTTEES_TFRISKCRISIS/Documents/turner_review.pdf. Accessed 22 Jan 2021

Financial Stability Board (2014a) Key attributes of effective resolution regimes for financial institutions. 15 October 2014. http://www.fsb.org/what-we-do/policy-development/effective-resol ution-regimes-and-policies/key-attributes-of-effective-resolution-regimes-for-financial-insti tutions/. Accessed 20 Oct 2020

Financial Stability Board (2014b) Structural banking reforms: cross-border consistencies and global financial stability implications. 27 October 2014. http://www.financialstabilityboard.org/wp-conte nt/uploads/r_141027.pdf. Accessed 19 Oct 2020

Financial Stability Oversight Council (2011) Study \& recommendations on prohibitions on proprietary trading \& certain relationships with hedge funds and private equity funds. Report. http://www. treasury.gov/initiatives/documents/volcker\%20sec\%20\%20619\%20study\%20final\%201\%2018\%20 $11 \% 20$ rg.pdf. Accessed 20 Oct 2020

FitchRatings (2011) Global trading and universal bank review: increased resilience but challenges remain. Fitch. http://pg.jrj.com.cn/acc/Res\%5CCN_RES\%5CINVEST\%5C2011\%5C12\%5C15\%5C147 5ee8b-ec01-404b-ba10-42e137106e0e.pdf. Accessed 20 Oct 2020

Freixas X, Giannini C, Hoggarth G, Soussa F (2000) Lender of last resort: what have we learned since Bagehot? J Financ Serv Res 18(1):63-84

Gambacorta L, Van Rixtel A (2013) Structural bank regulation initiatives: approaches and implications. BIS Working Paper No 412. http://www.bis.org/publ/work412.pdf. Accessed 20 Oct 2020

Gande A (2008) Commercial banks in investment banking. In: Thakor AVB, Boot AWA (eds) Handbook of financial intermediation and banking. Elsevier, Amsterdam, pp 163-188

Goddard J, Molyneux P, Wilson JOS, Tavakoli M (2007) European banking: an overview. J Bank Finance 31(7):1911-1935

Goodhart CAE, Wagner W (2012) Regulators should encourage more diversity in the financial system. VoxEU.org. http://voxeu.org/article/regulators-should-encourage-more-diversity-financial-syste m?quicktabs_tabbed_recent_articles_block $=1$. Accessed 20 Oct 2020

Gorton GB (2010) Slapped by the invisible hand: the panic of 2007. Oxford University Press, New York

Gorton GB, Metrick A (2010) Regulating the shadow banking system. Brook Pap Econ Act Fall 2010:261-312

Heffernan S (2005) Modern banking. Wiley, Chichester

Hsu J, Moroz M (2010) Shadow banks and the financial crisis of 2007-2008. In: Gregoriou GN (ed) The banking crisis handbook. CRC Press, Boca Raton, pp 39-56

Iannotta G (2010) Investment banking: a guide to underwriting and advisory services. Springer, Heidelberg

Independent Commission on Banking (2011) Final report: recommendations. September 2011. London. https://webarchive.nationalarchives.gov.uk/20120827143059/http://bankingcommission.indep endent.gov.uk/. Accessed 29 Apr 2019

James C (1992) Relationship-specific assets and the pricing of underwriter services. J Finance 47(5):1865-1885

Jones D (2000) Emerging problems with the Basel Capital Accord: regulatory capital arbitrage and related issues. J Bank Finance 24(1-2):35-58 
Kanatas G, Qi J (1998) Underwriting by commercial banks: incentive conflicts, scope economies, and project quality. J Money Credit Bank 30(1):119-133

Kay JA (2009) Narrow banking: the reform of banking regulation. Centre for the Study of Financial Innovation $(\mathrm{CSFI})$, London

Keeley MC (1990) Deposit insurance, risk, and market power in banking. Am Econ Rev 80(5):1183-1200

Kelly BT, Lustig H, van Nieuwerburgh S (2011) Too-systemic-to-fail: what option markets imply about sector-wide government guarantees. NBER Working Paper Series No 17149. http://www.nber.org/ papers/w17149. Accessed 20 Oct 2020

Krahnen J-P, Noth F, Schüwer U (2017) Structural reforms in banking: the role of trading. J Financ Regul 3(1):66-88

Kroszner RS, Rajan RG (1994) Is the Glass-Steagall Act justified? A study of the U.S. experience with universal banking before 1933. Am Econ Rev 84(4):810-832

Laeven L, Valencia F (2012) Systemic banking crises database: an update. http://papers.ssrn.com/sol3/ papers.cfm?abstract_id=2096234. Accessed 20 Oct 2020

Lehmann M (2016) Volcker Rule, ring-fencing or separation of bank activities - comparison of structural reform acts around the world (journal article). J Bank Regul 17(3):176-187

Lessig L (1996) The zones of cyberspace. Stanford Law Rev 48:1403-1411

Liikanen E (2012) High-level Expert Group on reforming the structure of the EU banking sector: Final report, 2 October 2012. Brussels. https://ec.europa.eu/info/publications/liikanen-report_en. Accessed 22 Jan 2021

Malysheva N, Walter JR (2010) How large has the federal financial safety net become? Econ Q Fed Reserve Bank Richmond 96(3):273-290

Morgan B, Yeung K (2007) An introduction to law and regulation: texts and materials. Cambridge University Press, New York

Morrison AD, Wilhelm W Jr (2007) Investment banking: institutions, politics, and law. Oxford University Press, New York

Nabilou H (2017) Bank proprietary trading and investment in private funds: is the Volcker Rule a panacea or yet another Maginot Line? Bank Finance Law Rev 32(2):297-341

Nabilou H, Pacces A (2018) The law and economics of shadow banking. In: Chiu IH, MacNeil IG (eds) Research handbook on shadow banking: legal and regulatory aspects. Edward Elgar Publishing Inc., Cheltenham, pp 7-46

Papageorgiou N, Salmon F (2010) The role of hedge funds in the banking crisis: victim or culprit. In: Gregoriou GN (ed) The banking crisis handbook. CRC Press, Taylor \& Francis Group, Boca Raton, pp 183-201

Pennacchi G (2012) Narrow banking. Annu Rev Financ Econ 4(1):141-159

Perino M (2010) The hellhound of Wall Street: how Ferdinand Pecora's investigation of the Great Crash forever changed American finance. The Penguin Press, New York

Pozsar Z, Adrian T, Ashcraft A, Boesky H (2013) Shadow banking. Fed Reserve Bank N Y Econ Policy Rev 19(2):1-16

Puri M (1996) Commercial banks in investment banking conflict of interest or certification role? J Financ Econ 40(3):373-401

Rajan RG (1992) Insiders and outsiders: the choice between informed and arm's-length debt. J Finance 47(4):1367-1400

Ramakrishnan RT, Thakor AV (1984) Information reliability and a theory of financial intermediation. Rev Econ Stud 51(3):415-432

Ratnovski L, Huang R (2009) Why are Canadian banks more resilient? IMF Working Paper WP/09/152. https://www.imf.org/en/Publications/WP/Issues/2016/12/31/Why-Are-Canadian-Banks-MoreResilient-23040. Accessed 20 Oct 2020

Richardson M, Smith RC, Walter I (2010) Large banks and the Volcker Rule. In: Acharya VV, Cooley TF, Richardson M, Walter I (eds) Regulating Wall Street: the Dodd-Frank Act and the new architecture of global finance. Wiley, Hoboken, New Jersey, pp 181-212. http://www.stern.nyu.edu/sites /default/files/assets/documents/con_044456.pdf. Accessed 20 Oct 2020

Saunders A (1985a) Conflicts of interest: an economic view. In: Walter I (ed) Deregulating Wall Street. Wiley, New York, pp 207-230

Saunders A (1985b) Securities activities of commercial banks: the problem of conflicts of interest. Bus Rev July/August:17-27

Saunders A (1994) Banking and commerce: an overview of the public policy issues. J Bank Finance $18(2): 231-254$ 
Saunders A, Walter I (2012) Financial architecture, systemic risk, and universal banking. Fin Mark Portf Manag 26(1):39-59

Schwarcz SL (2013) Ring-fencing. South Calif Law Rev 87:69-109

Sharpe SA (1990) Asymmetric information, bank lending and implicit contracts: a stylized model of customer relationships. J Finance 45(4):1069-1087

Shearman \& Sterling LLP (2014) Comparison of new EU proposals on proprietary trading and ring-fencing against US, UK, French and German rules. http://www.shearman.com/ /media/Files/NewsI nsights/Publications/2014/02/ComparisonofNewEUProposalsonProprietaryTradingFIAFR0226 14.pdf. Accessed 20 Oct 2020

Shleifer A (2010) Comments and discussions (Regulating the shadow banking system by Gary Gorton \& Andrew Metrick). Brook Pap Econ Act Fall 2010:298-303

Shull B, White LJ (1998) The right corporate structure for expanded bank activities. Bank Law J 115:446-476

Simons HC (1934) A positive program for laissez faire. University of Chicago, Chicago

Simons HC (1936) Rules versus authorities in monetary policy. J Polit Econ 44(1):1-30

Thakor A (2012) The economic consequences of the Volcker Rule. US Chamber of Commerce's Center for Capital Market Competitiveness. Summer 2012. https:/www.uschamber.com/sites/default/files/ legacy/reports/17612_CCMC\%20Volcker\%20Rule2.pdf. Accessed 20 Oct 2020

Vennet RV (2002) Cost and profit efficiency of financial conglomerates and universal banks in Europe. J Money Credit Bank 34(1):254-282

Viñals J, Fiechter J, Narain A, Elliott J, Tower I, Bologna P et al (2010) The making of good supervision: learning to say 'no'. IMF Staff Position Note SPN/10/08. https://www.imf.org/en/Publicatio ns/IMF-Staff-Position-Notes/Issues/2016/12/31/The-Making-of-Good-Supervision-Learning-toSay-No-23799. Accessed 20 Oct 2020

Viñals J, Pazarbasioglu C, Surti J, Narain A, Erbenova MM, Chow MJT (2013) Creating a safer financial system: will the Volcker, Vickers, and Liikanen structural measures help? International Monetary Fund

Walter I (2004) Conflicts of interest and market discipline among financial service firms. Eur Manag J 22(4):361-376

Walter JR (2005) Depression-era bank failures: the great contagion or the great shakeout? Fed Reserve Bank Richmond Econ Q 91(1):39-54

Weitzman ML (1974) Prices vs. quantities. Rev Econ Stud 41(4):477-491

White EN (1986) Before the Glass-Steagall Act: an analysis of the investment banking activities of national banks. Explor Econ Hist 23(1):33-55

Williams JL, Jacobsen MP (1995) The business of banking: looking to the future. Bus Lawyer 50(3):783-816

Yeung K (2008) Towards an understanding of regulation by design. In: Brownsword R, Yeung K (eds) Regulating technologies: legal futures, regulatory frames and technological fixes. Hart Publishing, Portland, pp 79-107

Zingales L (2009) The future of securities regulation. J Acc Res 47(2):391-425

Publisher's Note Springer Nature remains neutral with regard to jurisdictional claims in published maps and institutional affiliations. 